\title{
Evaluation of reanalysis and global meteorological products in Beas river basin of North-Western Himalaya
}

\author{
Tanmoyee Bhattacharya ${ }^{1 *}$, Deepak Khare ${ }^{1}$ and Manohar Arora ${ }^{2}$
}

\begin{abstract}
It is a great challenge to obtain reliable gridded meteorological data in some data-scarce and complex territories like the Himalaya region. Less dense observed raingauge data are unable to represent rainfall variability in the Beas river basin of North-Western Himalaya. In this study four reanalyses (MERRA, ERA-Interim, JRA-55 and CFSR) and one global meteorological forcing data WFDEI have been used to evaluate the potential of the products to represent orographic rainfall pattern of Beas river basin using hydrology model. The modeled climate data have compared with observed climate data for a long term basis. A comparison of various rainfall and temperature products helps to determine uniformity and disparity between various estimates. Results show that all temperature data have a good agreement with gridded observed data. ERA-Interim temperature data is better in terms of bias, RMSE (Root Mean Square Error), and correlation compared to other data. On the other hand, MERRA, ERA-Interim and JRA- 55 models have overestimated rainfall values, but CFSR and WFDEl models have underestimated rainfall values to the measured values. Variable Infiltration Capacity (VIC), a macroscale distributed hydrology model has been successfully applied to indirectly estimate the performance of five gridded meteorological data to represent Beas river basin rainfall pattern. The simulation result of the VIC hydrology model forced by these data reveals that the discharge of ERA-Interim has a good agreement with observed streamflow. In contrast there is an overestimated streamflow observed for MERRA reanalysis estimate. JRA-55, WFDEI, and CFSR data underestimate the streamflow. The reanalysis products are also poor in capturing the seasonal hydrograph pattern. The ERA-Interim product better represents orographic rainfall for the Beas river basin. The reason may be the ERA-Interim uses a four-dimensional variational analysis model during assimilation. The major drawback of MERRA is the non-inclusion of observed precipitation data during assimilation and modeling error. The poor performance of JRA-55, CFSR and WFDEl is due to the gauge rainfall data assimilation error. This research finding will help for broader research on hydrology and meteorology of the Himalayan region.
\end{abstract}

Keywords: MERRA, ERA-INTERIM, JRA-55, CFSR, WFDEI, CRU, VIC, Beas river basin

\section{Background}

Rainfall and temperature data are considered as a significant input for water resource management and hydrological processes of the Himalayan river basin. The high altitude precipitation is mainly dependent on orography. The other factors that control the variation of precipitation are space, time and altitude. The association of

\footnotetext{
*Correspondence: bhattacharya.tanmoyee36@gmail.com

1 Indian Institute of Technology, Roorkee, Uttarakhand, India

Full list of author information is available at the end of the article
}

orography with broad atmospheric circulation system, zonal climate process and rate of local evapotranspiration control the pattern of distribution and variability of mountain precipitation (Nesbitt and Anders, 2009). Therefore it is necessary to evaluate the precipitation estimates to understand the spatio-temporal distribution of mountain precipitation. Several studies (Bhattacharya et al. 2019; Tiwari et al. 2018) have reported the advantage of using reanalysis temperature products for snowmelt modeling and simulation of streamflow in high altitude rugged terrain where observation networks 
are inaccessible. A comparison of various reanalysis temperature estimates with observation is needed to understand the variability of temperature with altitude and to estimate suitable gridded temperature data as a proxy of observation stations for data- limited mountain regions. Ledesma and Futter (2017) have reported that the observed air temperature from a station is more realistic than rainfall. The spatial variation and error in the station air temperature are less as compared to precipitation. For the Himalayan river basin the major challenges are less spatial coverage of raingauge data, difficulty in data collection and missing data. This will reduce the capability of raingauge stations to accurately capture the spatiotemporal variability of rainfall (Liu and Zipser 2014; Palazzi et al. 2013). Due to data scarcity the management and assessment of water resources are much needed for remote regions (Buytaert et al. 2012). The region where orography is complex and human settlement is less regular grids to be created by reanalysis and satellite retrievals to fill the lack of observations in an ungauged basin (Bai and Liu 2018). Many studies have suggested that higher frequency events better acquired by high spatial resolution climate data (Ward et al. 2011; Fuka et al. 2014). The performance of satellite precipitation products in the mountain region is dependent on complex topography, change of elevation, snow cover and seasonality. The reason of error in quantification of satellite precipitation events may be due to sampling error, error due to algorithms and instruments. The satellite rainfall data also have limitations of their short length of record (Derin and Yilmaz 2014). To address these challenges of datascarce basin high-resolution global reanalysis data have been widely used for hydrology models around the world (Zhao et al. 2010). Global forcing data developed using bias-correction (based on observation) of reanalysis data are also preferred nowadays for hydrological studies in mountain regions. The reanalysis products are gridded data at different spatial and temporal scales to represent the state of the atmosphere using the output of numerical atmospheric models, different data assimilation techniques and multiple observed datasets for multiple variables (humidity, temperature, solar radiation etc.) (Dee et al. 2011; Chen and Liu 2016). Climate reanalysis mechanic combines the model result with observation at regular grids. The reanalysis data are available for almost every region of the earth and a long term basis (Caroletti et al. 2019). Additionally the reanalysis products are not limited to topography and provide high-resolution precipitation at a quasi-global scale. The grid point distance of the reanalysis data is quasi-uniform. Therefore, the reanalysis estimates can be used to investigate the rainfall spatial variability on streamflow in mountain areas and provide long-term records (Lobligeois et al. 2014; Zhao et al. 2013). The individual performance of different reanalysis products depends on the assimilation of different portions of input observations, model physics, observing techniques, data assimilation schemes, available observations and resolutions (Lin et al. 2014; Haylock et al. 2008; Shea et al. 1994, Bao and Zhang 2013). As a result, the applicability of the reanalysis products differs by region and evaluation plans (Essou et al. 2016a, b). The performance of different reanalysis data on a regional and global scale has carried out by many studies. The studies reveal that the large-scale performance of these data is useful but shows considerable variability at the regional scale. For example, Janowiak et al. (1998) have found a good agreement between National Centers of Environmental Prediction (NCEP) - National Center for Atmospheric Research (NCAR) and Global Precipitation Climatology Project (GPCP) raingauge-satellite combined data when compared at the global scale. However, these reanalysis data perform poorly on a regional scale. Lin et al. (2014) concluded that the seasonality of global Monsoon precipitation is correctly reproduced by MERRA (Modern-Era Retrospective Analysis for Research and Applications) and European Center for Medium-Range Weather Forecasts (ECMWF) ERA-Interim reanalysis data. Essou et al. (2016a, b) have compared the output of the hydrology model using global and regional reanalysis data in the United States. The reanalysis data show their potential to reproduce interannual variability of rainfall except for subtropical and humid continental regions. According to Hodges et al. (2011) Climate Forecast System Reanalysis (CFSR), MERRA and ERA-Interim perform better in Southern Hemisphere. So, it is necessary to review the efficiency of different reanalysis estimates in a particular region, especially in the mountain regions. Furthermore the measurement bias of precipitation between reanalysis and observed rainfall in the mountain regions is due to changing observation systems, low elevation stations and gauge undercatch problems (Fujiwara et al. 2017; Rasmussen et al. 2012; Li 1995). The researches reveal that the reanalysis products are improving with the development of data assimilation method, numerical modeling and increased computing power. The assessment of variability, trend and uncertainty is therefore needed before using reanalysis products in the climate study (Parker 2016). The representation of spatio-temporal processes by distributed hydrology model needs precipitation as the most important driver variable (Thiemig et al. 2013). The inferior quality of temperature and rainfall data due to observation and data processing error can be responsible for poor model efficiency in generating streamflow. Nowadays the hydrology models have been used to evaluate precipitation properties of the catchment by calibrating them to observed discharge. Due to high variability 
and dependency on station network the discharge observations are also utilized to correct orographic precipitation in the elevation zone. Several studies have conducted to evaluate the precipitation estimates based on streamflow simulation by hydrology modeling framework (Bai and Liu 2018; Sun et al. 2018; Li et al. 2015; Tong et al. 2014a, b; Mei et al. 2016). These researches have assumed that the error of rainfall products can be communicated into the simulated discharge. Even many studies have suggested that the best accessible evidence for catchment precipitation in the data-scarce basin is discharge which is superior to suggested meteorological observations (Duethmann et al. 2013; Henn et al. 2015; Sevruk and Mieglit 2002).

The structural error (incorrect description of processes), the error generated by model parameters and input data error are the main reasons for modeling uncertainty. The uncertainties from various sources are a crucial challenge for hydrological simulation. Therefore the improvement of hydrology models is needed to improve model efficiency and reduce uncertainty (Beven, 2006; Clark et al. 2011). Energy-balance based distributed high-resolution hydrology model more precisely analyze the sensitivity of the hydrology cycle in snow and glacierfed river basin by following the process-based physical rules. The model's grid-based configuration allows it to be coupled directly to land-surface schemes and highresolution climate models. The advantage of using the model over widely used temperature-index and degreeday model is- (i) simulation of complex events like rain on snow, (ii) snowpack melting where the only temperature has no direct correlation with energy, (iii) different physical aspects of generating runoff and snow/glacier melt runoff, (iv) describing the glacio-hydrology physical processes to reduce parameter uncertainty (Walter et al. 2005; Shrestha et al. 2015). The spatial variability of subcatchment elements is usually described by the distributed models using a node-link structure instead of spatial averaging (Zoppou, 2000) done by the lumped model to describe catchment behavior. One of the process-based distributed hydrology models is the Variable Infiltration Capacity (VIC) hydrology model. However very few studies have used VIC hydrology model to compare gridded rainfall dataset in the mountainous region (Yanto and Rajagopalan 2017; Tong et al. 2014a, b; Islam and Dery 2017). These studies prove that the streamflow quality depends on input forcing, model set up and capability.

The Beas river basin is a topographically complex, mountainous, high altitude and data-scarce Himalayan river basin. The elevation of the basin varies from 361 to $6188 \mathrm{~m}$. The gauge and discharge stations are located at elevations ranging from $436 \mathrm{~m}$ at pong dam to $904 \mathrm{~m}$ at Pandoh dam and $2050 \mathrm{~m}$ at Manali. For the Beas river basin $21 \%$ area above $4800 \mathrm{~m}$ exists above sea level. At this elevation little or no weather stations exists. For this reason, reliable snowfall measurements are scarce by the raingauges at this elevation. According to Kumar et al. (2007) no observation stations are located in the Eastern part of the basin. Therefore the reliable gridded reanalysis meteorological data can be used as a proxy of observation stations for the hydro-climatic assessment in the Beas river basin. The reanalysis temperature data can also be used as the best parameter for snowmelt modeling of upper Beas where $65 \%$ of area is covered with snow during Winter (Singh and Jain 2002) and no observations exist. Very few studies have conducted to evaluate the performance of observed, satellite and model-generated precipitation for the Beas river basin of NorthWestern Himalaya (Li et al. 2013; 2015; Li et al. 2017). They have also applied conceptual and temperature index hydrology models using gridded precipitation data for a short term basis. Most of the studies have estimated streamflow for a single location. The finding of those studies is the underestimated streamflow as compared to observed data. But no studies have examined various high-resolution gridded reanalysis data for process-based distributed hydrology models to investigate their capability to represent precipitation patterns of the Beas river basin. The variability of reanalysis temperature and precipitation with observations has also not evaluated in previous research. This study focuses on these research gaps by assessment of various gridded reliable meteorological data. In this research a thorough assessment of five widely used reanalysis and global meteorological products [Modern-Era Retrospective Analysis for Research and Applications (MERRA), European Center for Medium-Range Weather Forecasts (ECMWF) ERA-Interim reanalysis, Japanese 55 year Reanalysis (JRA-55), Climate Forecast System Reanalysis (CFSR) and WATCH forcing data methodology applied to ERA-Interim (WFDEI)] are undertaken by direct comparison of these products with observations and evaluating these estimates by utilizing the hydrology model in the data-scarce Beas river basin. The modeling approach has also used in this study to understand the variability of orographic precipitation in Beas. Moreover, streamflow using reanalysis products has estimated for different locations of different elevations to consider the effect of topography on discharge. The purpose of the study is to evaluate the quality of the reanalysis products for hydrology research using a process-based distributed Variable Infiltration Capacity hydrology model (VIC) and how well each data reproduces spatial rainfall patterns for Beas river basin. One of the limitations of the study is the non-availability of point temperature data 
from weather stations. Therefore, the global monthly observed gridded Climate Research Unit (CRU) temperature data has been used for comparison purposes.

\section{Study area}

The area selected for the study is the Beas basin (up to Pong dam) lies in the North- Western part of the Indian Himalayan Region (Fig. 1). It has an elevation of $4361 \mathrm{~m}$ $(14,308 \mathrm{ft})$ and is situated at geographical co-ordinates $32^{\circ}$ $21^{\prime} 59^{\prime \prime}-31^{\circ} 16^{\prime} 09^{\prime \prime} \mathrm{N}$ and $77^{\circ} 05^{\prime} 08^{\prime \prime} \mathrm{E}-74^{\circ} 58^{\prime} 31^{\prime \prime} \mathrm{E}$. The catchment area of the basin is $12,417 \mathrm{~km}^{2}$. The snow-covered and glaciated portion of the basin in upper reaches contributes meltwater to streamflow. The Winter season of Beas river basin has an average maximum temperature of $14.1{ }^{\circ} \mathrm{C}$ to a minimum of $0.22{ }^{\circ} \mathrm{C}$. The average rainfall during April-June has estimated to be $106.12 \mathrm{~mm}$. During Summer, temperature varies from a maximum of 24.6 ${ }^{\circ} \mathrm{C}$ to a minimum of $8.9{ }^{\circ} \mathrm{C}$, and average rainfall during this season is $86.83 \mathrm{~mm}$. The Monsoon months (JuneSeptember) receive $70 \%$ of the annual rainfall. There is an occurrence of severe snowfall for this basin during Winter. Whereas the basin gets small amounts of rain from October to November (Ahluwalia et al. 2015).

\section{Data and methodology}

\section{Data used}

The hydro-meteorological data play a crucial role in computing streamflow, rainfall-runoff, and Beas river basin's snow component. The hydro-meteorological data used as an input for the hydrology models are daily maximum, minimum temperature, rainfall, wind speed and streamflow. Daily observed point rainfall and streamflow from 1990 to 2009 for raingauge stations are obtained from Bhakra Beas Management Board, Himachal Pradesh. The raingauge stations are Banjar, Bhuntar, Janjehal, Larji, Manali, Pandoh, Pong, and Sainj. The streamflow data for 1990-2009 is obtained for the Pong dam, Pandoh dam, Thalout and Manali. The spatial distribution of precipitation and temperature data over the Beas river basin during different seasons has shown in Figs. 2 and 3. Instead of using an available huge number of data and surface fluxes layers only 4 parameters at daily scale has been used. The algorithm developed by Maurer et al. (2002) has been used to calculate the meteorological data such as vapor pressure, incoming shortwave radiation and net longwave radiation for Variable Infiltration Capacity hydrology model. The reanalysis and global meteorological data have used in this study are MERRA, ERA-Interim, JRA-55, CFSR and WFDEI. CFSR has a horizontal resolution of $38 \mathrm{~km}$ spanning the period of 1st January 1979 to the present day (Saha et al. 2014). CFSR has a 3D-variational analysis scheme of the upper-air atmospheric state with 64 vertical levels. The WFDEI Forcing data (Weedon et al. 2014) is produced from Watch forcing data and ERA-Interim reanalysis data. The mechanic follows sequential interpolation to a $0.5^{\circ}$ resolution,

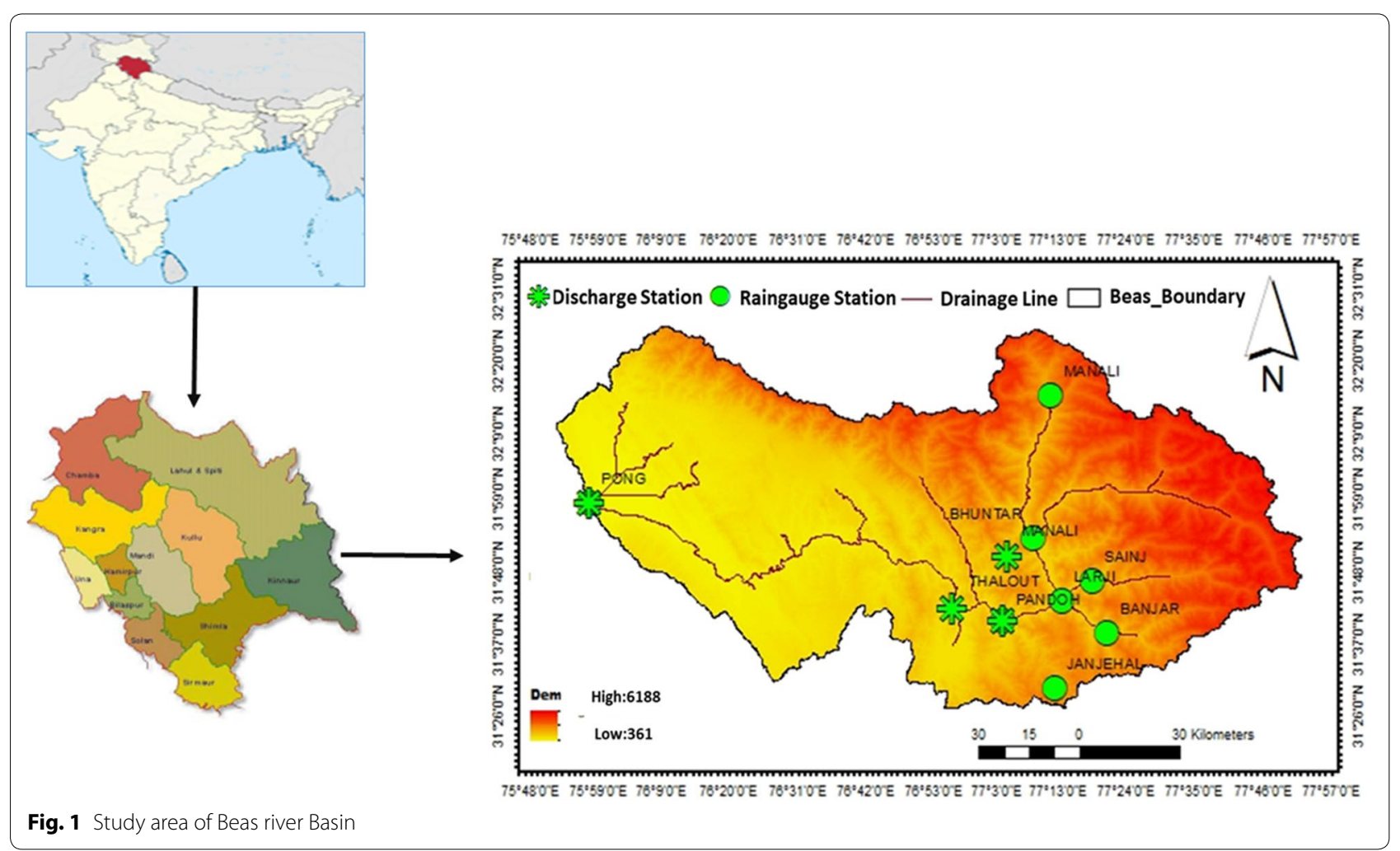




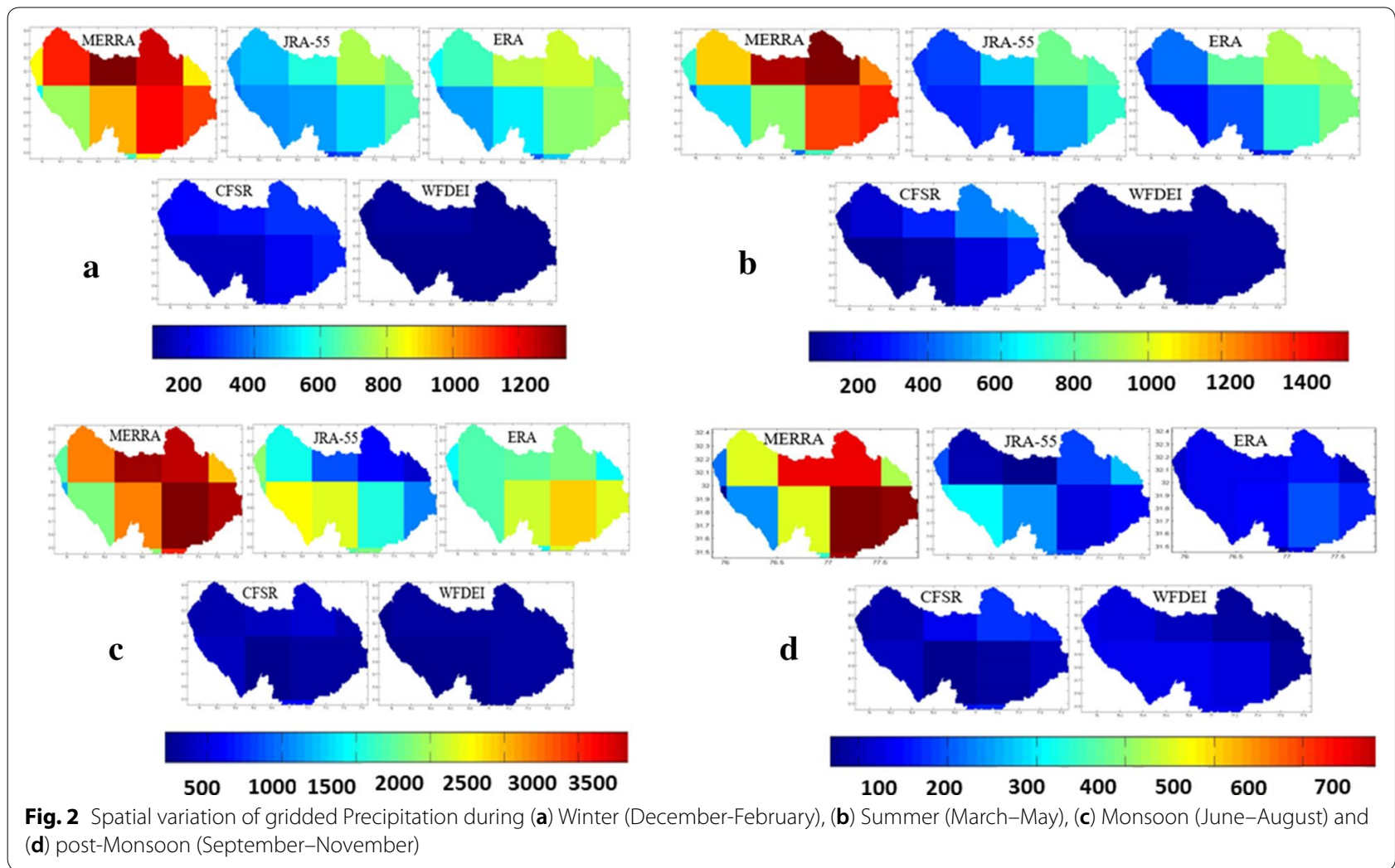

elevation correction and monthly-scale adjustments. The monthly-scale adjustment is based on CRU TS3.1/TS3.21 and GPCCv5/v6 monthly precipitation observations for 1979-2012. Global Modeling And Assimilation Office (GMAO) of the National Aeronautics and Space Administration (Rienecker et al. 2011) develops global MERRA. MERRA covers the satellite era (from 1979 to the present). MERRA is generated from the Goddard Earth Observing System Model, version 5.2.0 (GEOS-5.2.0) and a data assimilation system based on a three-dimensional variational approach (3DVAR). The Japan Meteorological Agency (JMA) conducted JRA-55 (Japanese 55-year reanalysis), the second Japanese global atmospheric reanalysis project. It covers 55 years, extending back to 1958. Compared to it's predecessor, JRA-55 is based on new Data Assimilation And Prediction System (DA) that improves many deficiencies found in the first Japanese reanalysis (Kobayashi et al. 2015). ERA-Interim is the latest global atmospheric reanalysis produced by the European Centre for Medium-Wave Forecasts (ECMWF) and covers the period from 1st January 1979 to the present day (Dee et al. 2011). MERRA and ERA-Interim have a high spatial resolution of $0.5 \times 0.67^{\circ}$ (Rienecker et al. 2011) and $0.75 \times 0.75^{\circ}$ (Dee et al. 2011). JRA-55 data also has a high spatial resolution of $1.25 \times 1.25^{\circ}$. CFSR and
WFDEI have a less spatial resolution $\left(0.5 \times 0.5^{\circ}\right)$ than other reanalysis data. All the temperature and rainfall data are interpolated to $0.5^{\circ}$ by bilinear interpolation to make consistency among all datasets. Table 1 gives information on various reanalysis and global meteorological data sources.

The spatial data has used for the Variable Infiltration Capacity hydrology model are the Digital Elevation Model (DEM), LULC (Land use and land cover) and soil data. Elevation, basin and slope are derived from Aster DEM at $30 \mathrm{~m}$ resolution. Land use and land cover data $(100 \mathrm{~m})$ are obtained from Oak Ridge National Laboratory (ORNL) Distributed Active Archive Center (DAAC) for the year 2005 (Roy et al. 2015). The LULC product is comprised of water body, evergreen broadleaf forest, deciduous broadleaf forest, mixed forest, wasteland, grassland, shrubland, plantation, cropland, built-up and snow-ice classes. The other vegetation properties are taken from Global Land Data Assimilation System (GLDAS) vegetation parameter database. Soil map and information has obtained from the National Bureau of Soil survey and land use planning (NBSS\&LUP) at 1:250 000 scale. The Elevation band parameter for the Variable Infiltration Capacity hydrology model is obtained from DEM. The elevation bands 

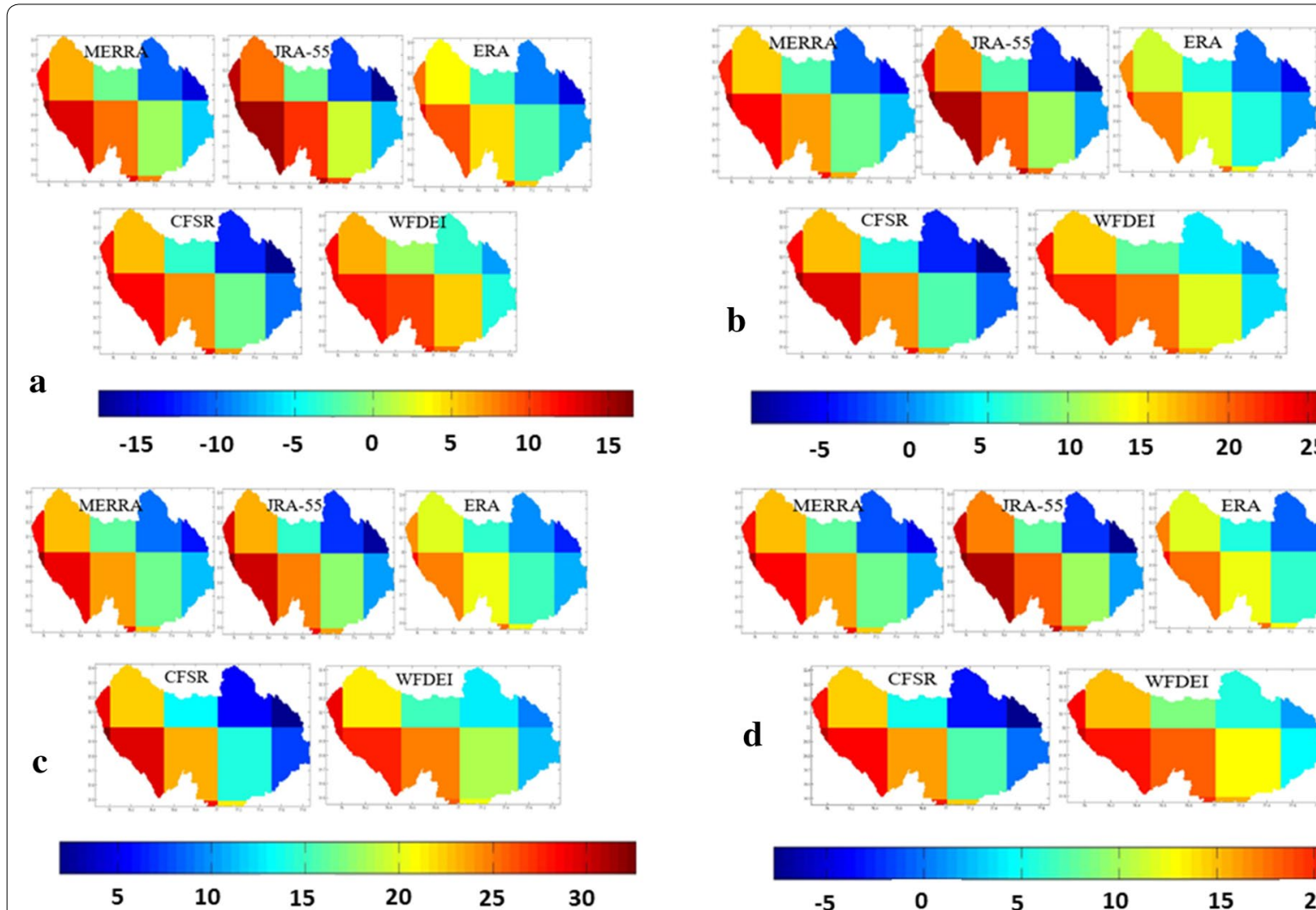

b
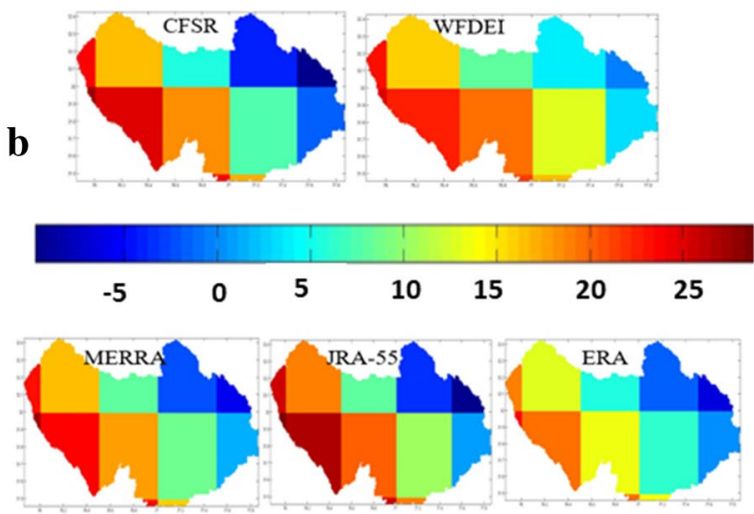

d
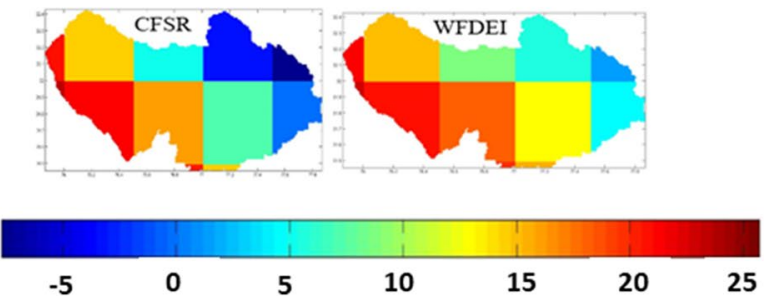

Fig. 3 Spatial variation of gridded temperature during (a) Winter (December-February), (b) Summer (March-May), (c) Monsoon (June-August) and (d) post-Monsoon (September-November)

Table 1 Description of various reanalysis and global meteorological data

\begin{tabular}{|c|c|c|c|}
\hline No & Rainfall product & Availability & Period \\
\hline 1 & MERRA & $\begin{array}{l}\text { Global (NASA Modeling and Assimilation Data and Information Services Center (MDISC) (https://disc.sci.gsfc. } \\
\text { nasa.gov/mdisc) }\end{array}$ & 1979-present \\
\hline 2 & ERA-Interim & $\begin{array}{l}\text { Global (ECMWF as part of Copernicus Climate Change Services) } \\
\text { (https://apps.ecmwf.int/datasets/data/interim-full-daily/levtype }=\mathrm{sfc} / \text { ) }\end{array}$ & 1979-present \\
\hline 3 & $J R A-55$ & $\begin{array}{l}\text { Global (NCAR Computational Information Systems Laboratory (CISL) Research Data Archive (RDA; https://rda. } \\
\text { ucar.edu) }\end{array}$ & 1958-2012 \\
\hline 4 & CFSR & $\begin{array}{l}\text { Global (National Centers for Environmental Information (NCEl; www.ncdc.noaa.gov/data-access/model-data/ } \\
\text { model-datasets/climate-forecast-system-version2-cfsv2) }\end{array}$ & 1979-2009 \\
\hline 5 & WFDEI & $\begin{array}{l}\text { Global (Produced post-WATCH using WFD methodology applied to ERA-Interim data) obtained from the Inter- } \\
\text { national Institute for Applied Systems Analysis (ftp://rfdata:forceDATA@ftp.iiasa.ac.at) }\end{array}$ & $1901-2012$ \\
\hline
\end{tabular}

up to ten have been used for the hydrology model. The elevation bands are used to derive elevation wise snow area fraction and glacier area fraction of each grid cell. Permanent snow line of the the basin lies above $5000 \mathrm{~m}$ and minimum snow line varies from 1800 to $2000 \mathrm{~m}$ (Aggarwal et al. 2016).

Gridded observed monthly temperature data for 1990-2009 has collected from CRU TS 3.22 (Climate
Research Unit time series). According to Harris et al. (2014) CRU TS 3.22 extends from the year 1901-2013 and is an interpolation of 0.5-degrees of latitude-longitude climate data.

DEM, slope, LULC (Land use and land cover) and soil map for Beas basin shown in Fig. 4. Elevation band parameter for the VIC hydrology model is obtained from DEM (Fig. 5). 


\section{Methodology used}

It is a great challenge for interpolated coarse resolution reanalysis data to reproduce rainfall spatial pattern in the mountain regions. Due to the non-reliability of observed raingauge the basin-scale validation of precipitation is less studied. In this research an attempt has been made to understand the ability of reanalysis data as a proxy of observation and their ability to produce spatio-temporal rainfall patterns of the Himalayan Beas river basin. Figure 6. presents the methodology flowchart of this research. The below-mentioned methods have carried out using the following steps:

1. All the gridded reanalysis data, in NETCDF (Network Common Data Form) format has processed in Linux (Lovable intellect not using XP) platform and the rainfall data for each station has extracted according to latitude and longitude in notepad for a specific time period.

2. The temperature and rainfall data from ERAInterim, MERRA and JRA-55 reanalysis estimates have converted to 0.5 -degree resolution by bilinear interpolation method to compare reanalysis, global meteorological and raingauge data. The validation of temperature data has done gridwise. Whereas point to pixel comparison has done for modeled and observed rainfall data. The evaluation of temperature and precipitation data has carried out at mothly and annual scale using various statistical indices.

3. The simulation of the VIC hydrology model has done using reanalysis and global meteorological data.

4. A comparison of simulated streamflow with observed discharge data has carried out using calibration and validation for five different raw and bias-corrected reanalysis products, which is similar to the research methodology of Bai and Liu 2018.

\section{Data comparison: temperature and precipitation}

Due to the coarser spatial resolution and assimilation of limited observations the quality of reanalysis temperature and precipitation is needed to be compared with observed climate data before applying for the hydrology model (Essou et al. 2016a, b). In the present study the mean annual cycles and monthly climate data are calculated and compared for individual stations of the Beas river basin. For each climatic region bias, correlation and Root Mean Square Error (RMSE) are calculated between reanalysis, global meteorological data and observed
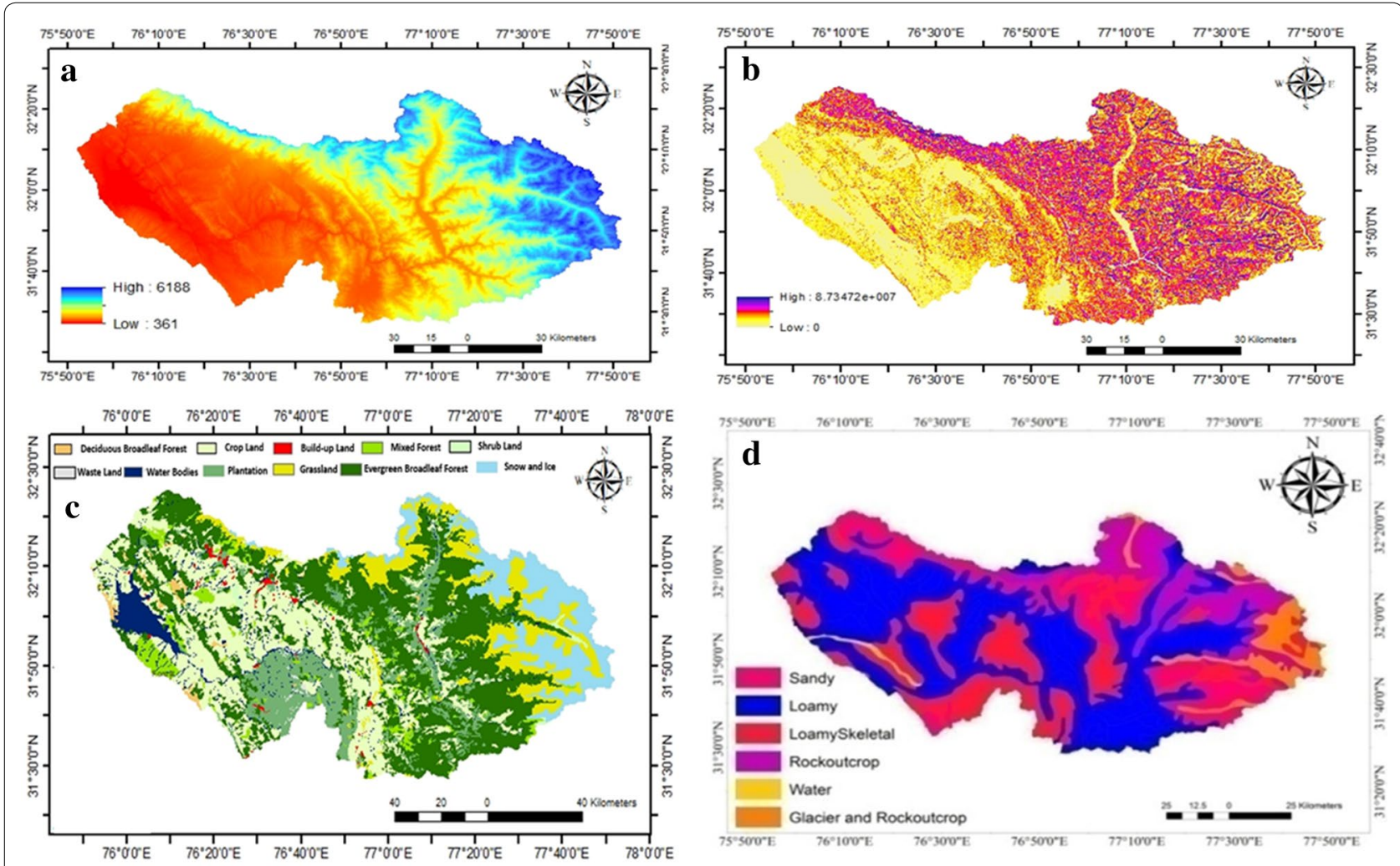

Fig. 4 a DEM map, b Slope map, c LULC map, and $\mathbf{d}$ Soil map of Beas basin 


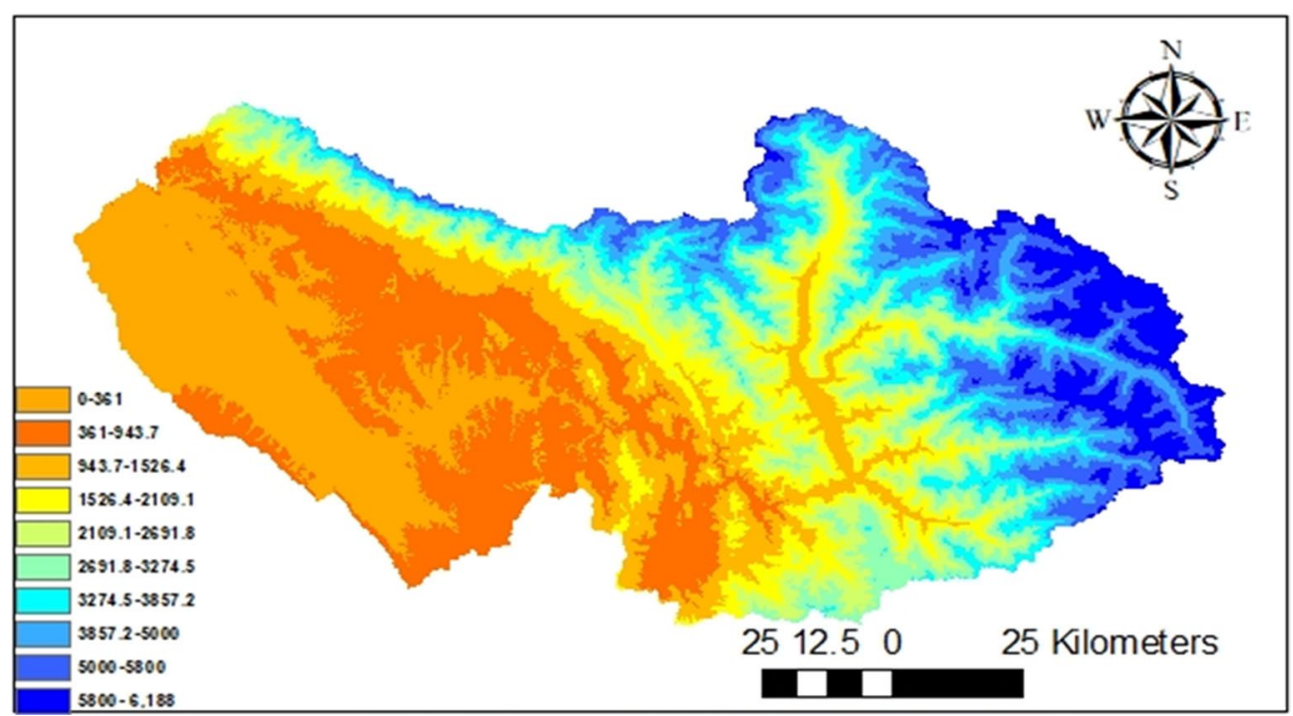

Fig.5 Elevation zone map of the basin

climate data. The bias for temperature and precipitation has calculated for the Winter (December-February), Summer (March-May), Monsoon (June-August) and post-Monsoon (September-November) period. Over a given period of time bias is the difference between temperature and precipitation data with observations. The overestimation and underestimation of rainfall and temperature data with observation are estimated by bias. The positive bias indicates overestimation and negative bias indicates underestimation. In comparison a perfect fit is indicated by null bias. The formula of bias is given in Eq. 1. RMSE is a measure of the deviation between the model and observed climate data (Eq. 2). The correlation coefficient $(r)$ calculates the strength of the relationship between the relative movements of observed and modeled forcing data. A correlation of -1.0 indicates a perfect negative correlation while a correlation of 1.0 shows a perfect positive correlation (Eq. 3).

$$
\begin{aligned}
& \operatorname{Bias}(\%)=\frac{P_{i}-O_{i}}{O_{i}} \times 100 \\
& R M S E=\sqrt{1 / n \sum\left(P_{i}-O_{i}\right)^{2}} \\
& \mathrm{r}=\frac{n\left(\sum P_{i} \times O_{i}\right)-\left(\sum P_{i}\right) \times\left(\sum O_{i}\right)}{\left.\sqrt{\left[n \sum O_{i}^{2}\right.}-\left(\sum O_{i}\right)^{2}\right]\left[n \sum P_{i}^{2}-\left(\sum P_{i}\right)^{2}\right.}
\end{aligned}
$$

$\mathrm{P}_{\mathrm{i}}$ is modeled data and $\mathrm{O}_{\mathrm{i}}$ is observed data.

In this study grid to point comparison has been made to compare reanalysis and global meteorological precipitation data with raingauge data. Bilinear interpolation has been used for comparing gridded rainfall with ground observation rainfall data for eight stations Banjar, Bhuntar, Janjehal, Larji, Manali, Pong dam, Pandoh dam and Sainj at monthly scale.

\section{Variable infiltration capacity hydrology model}

Variable Infiltration Capacity hydrology model (VIC) is a semi-distributed, grid-based macroscale hydrology model (Nijssen et al. 1997; Liang et al. 1994). VIC hydrology model uses grid wise daily inputs of vegetation parameter, snow parameter, soil parameter, elevation and daily meteorological forcing parameters. The VIC hydrology model considers the effect of vegetation, topography and soil at daily or sub-daily time steps. VIC, process-based hydrology model simulates surface runoff, evapotranspiration, baseflow, snowpack and other hydrologic processes. A large number of parameters are required to run the VIC hydrology model i.e. vegetation, soil, elevation and meteorological forcing at each grid cell. The Beas river basin runoff not only dependant on precipitation. The topography, soil and land cover also have a significant impact on runoff. The finer resolution inputs (topographic, land cover and forcing data) in distributed hydrology models can reduce simulation uncertainty (Haddeland et al. 2002). Therefore the VIC hydrology model has implemented over the entire Beas river basin at spatial resolution $0.01 \times 0.01^{\circ}$. The meteorological forcing (temperature and rainfall) data are converted to $0.01^{\circ}$ resolution from $0.5^{\circ}$ resolution by interpolation. The soil, LULC and DEM are also converted to $0.01^{\circ}$ resolution by resampling. The mosaic scheme is one of 


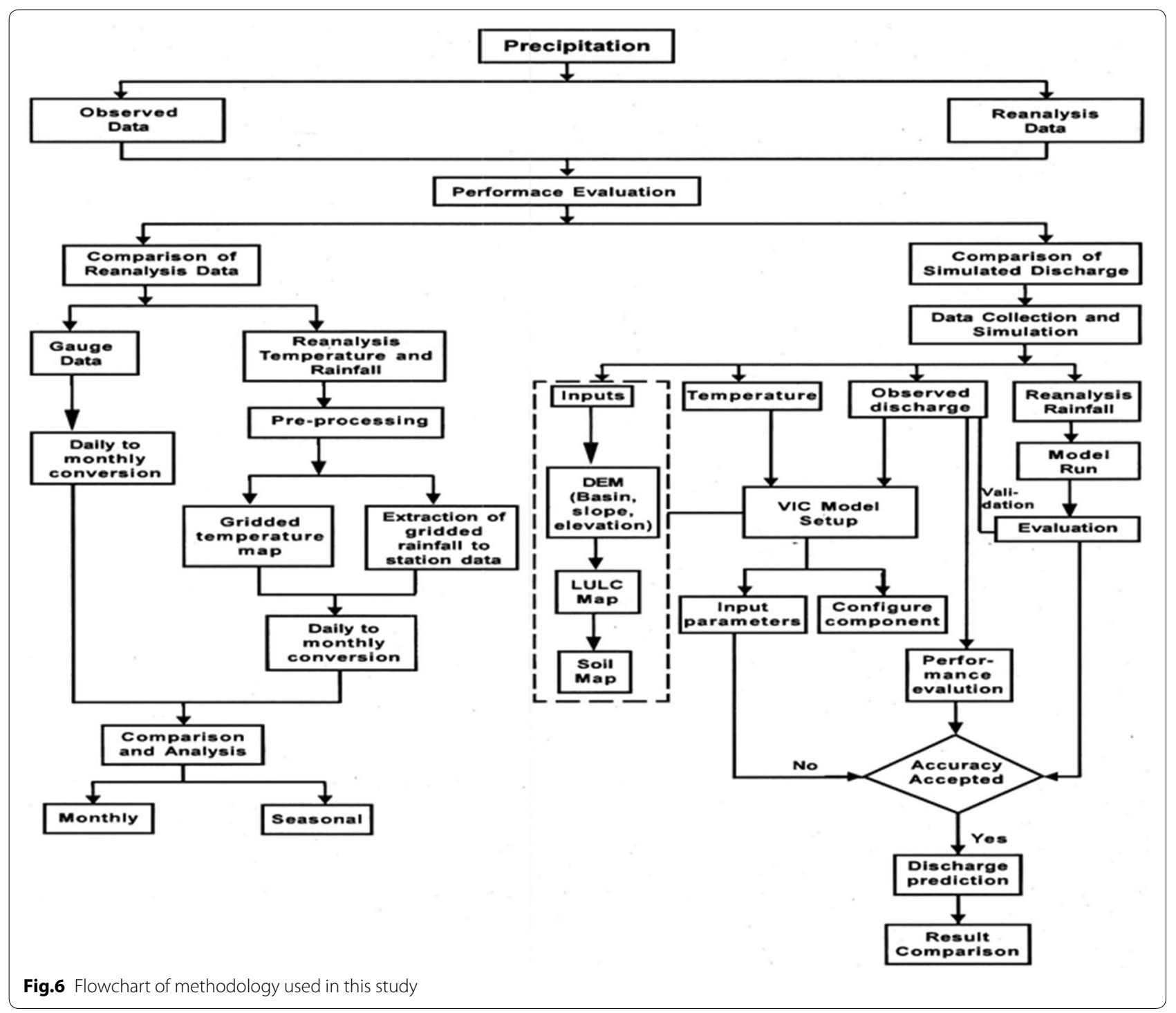

the unique characteristics of the VIC hydrology model. The soil information of the VIC hydrology model of total depth 0 to $2.5 \mathrm{~m}$ is divided into three layers. The total number of soil parameters required for the VIC hydrology model are initial soil moisture, bulk density, saturated hydraulic conductivity, the thickness of layer, soil moisture fraction at wilting point and variable infiltration curve parameter $\left(b_{\text {infilt }}\right)$. The average annual air temperature, average annual precipitation, slope and average elevation are the non-soil parameters in the soil parameter file. The vegetation parameter file for the VIC hydrology model is generated based on LULC classes fractional area over a particular grid including it's rooting depth. Information from Global Land Data Assimilation System (GLDAS) vegetation parameter database is used to collect information about other vegetation properties. For each grid vegetation information is derived from monthly Leaf area index (LAI) and ALBEDO for the period 2003-2008. A routing model has implemented in the VIC hydrology model where fractional values at each grid cell flow and flow direction are considered as input files. Surface runoff and baseflow are routed to basin outlet through stream network. Elevation band information in the VIC hydrology model (fraction of grid area with their corresponding elevation) is needed for better representation of snowmelt and snow accumulation. A snow model of two layer energy balance and a frozen soil/permafrost algorithm is used in the hydrology model for cold land implementation (Cherkauer and Lettenmaier 1999). The VIC hydrology model is also integrated with a glacier scheme. The glacier scheme can simulate glacier runoff $(\mathrm{mm})$ from the glaciated area, including liquid precipitation and snow/ 
glacier melt water. In this study VIC model simulation has been done in energy balance mode to estimate snowmelt/glacier melt runoff.

The selection of calibration parameters plays an important role in controlling infiltration and baseflow factors that regulate the streamflow hydrograph. According to Nijssen et al. (1997) the parameters to be adjusted during calibration of the VIC hydrology model are infiltration parameter (b_inf), the depth of the first and second soil layers (d1, d2), and three baseflow parameters (Ds, Ws, Dsmax). The parameter b_inf defines the shape of the variable infiltration capacity curve and the range has taken 0-0.4. Enhanced runoff production is due to an increase in b_inf. Whereas a reduced runoff is due to a decrease in b inf. The soil thickness controls the soil moisture storage capacity. Thick soil depth has higher moisture storage capacity, less runoff, higher evapotranspiration and higher baseflow. The amount of water for transpiration and baseflow is controlled by the thickness of the bottom soil layer (d2). The ranges for the first and bottom soil layer varies from $0.05-0.25 \mathrm{~m}$ and $0.3-1.50 \mathrm{~m}$. The maximum baseflow from the lowest soil layer (Dsmax) ranges from 0 to 30 depending on the soil's hydraulic conductivity. Ds is the fraction of Dsmax where the rapidly increasing nonlinear baseflow starts. The value of Ds ranges from 0 to 1 . Higher baseflow occurs due to a higher value of Ds. Ws is the fraction of the maximum soil moisture of the lowest soil layer. The higher value of Ws tends to delay the peak runoff. The calibration and validation have conducted for each reanalysis and global meteorological data. The magnitude of different calibration parameters for the Pandoh dam and Thalout has shown in Figs. 7 and 8. The ranges of parameters vary for different rainfall data.

The agreement of simulated and observed streamflow during calibration and validation is judged by statistical parameters like: NSE (Nash Sutcliffe Efficiency), Coefficient Of Determination $\left(R^{2}\right)$, Root Mean Square Error (RMSE) and PBIAS (Percentage Bias). $R^{2}$ is the squared ratio between covariance and multiple standard deviations of observation and modeled data. The $\mathrm{R}^{2}$ ranges between $0-1$ and indicate the relation between predicted and observed dispersion. Nash Sutcliffe efficiency varies between $-\infty$ to 1 (perfect fit) (Moriasi et al. 2007). PBIAS indicates the overestimation and underestimation tendency of the simulated data with observed value (Gupta et al. 1999). The RMSE value indicates the match between observed and modeled data with perfect value 0 . The poor match is indicated by increased RMSE value (Moriasi et al. 2007). The lower the RMSE value the better the model performance.

$$
\begin{aligned}
& \mathrm{NSE}=1-\left[\sum_{I=1}^{N}\left(Q_{o b s}-Q_{s i m}\right)^{2} / \sum_{I=1}^{N}\left(Q_{o b s}-Q_{o b s}^{\text {mean }}\right)^{2}\right] \\
& \mathrm{R}^{2}=\frac{\left(\sum\left(Q_{o b s(t)}-\bar{Q}_{o b s}\right)\left(Q_{s i m}(t)-\bar{Q}_{s i m}\right)\right)^{2}}{\sum\left(Q_{o b s(t)}-\bar{Q}_{o b s}\right)^{2} \sum\left(Q_{s i m}(t)-\bar{Q}_{s i m}\right)^{2}} \\
& \mathrm{PBIAS}=\left[\sum_{I=1}^{N}\left(Q_{o b s}-Q_{s i m}\right) * 100 / \sum_{I=1}^{N}\left(Q_{o b s}\right)\right] \\
& \mathrm{RMSE}=\sqrt{\sum_{I=1}^{N}\left(Q_{o b s}-Q_{s i m}\right)^{2} / N}
\end{aligned}
$$

$\mathrm{Q}_{\mathrm{obs}}$ and $\mathrm{Q}_{\text {sim }}$ are the average observed and simulated discharge. $Q_{o b s}(t)$ and $Q_{\text {sim }}(t)$ are the observed and simulated discharge at time $\mathrm{t}, \mathrm{N}$ is the number of observation.

\section{Results}

\section{Comparison of modeled and observed temperature}

The 2-m average maximum, minimum and mean temperatures for the Beas river basin are compared for ERA-Interim, JRA-55, MERRA, CFSR and WFDEI. All the rainfall products are interpolated to 0.5-degree resolution. Figure 9 shows the monthly maximum, minimum and mean temperature of each reanalysis and global meteorological data. The monthly maximum temperature for ERA-Interim, JRA-55, MERRA, CFSR and WFDEI varies from $4.18-21.49{ }^{\circ} \mathrm{C}, 4.52-23.91{ }^{\circ} \mathrm{C}$, 6.56-25.86 ${ }^{\circ} \mathrm{C}, 1.82-20.73{ }^{\circ} \mathrm{C}$ and $7.07-24.47{ }^{\circ} \mathrm{C}$. The ranges of minimum temperature for all climatic data are $-7.20-14.48{ }^{\circ} \mathrm{C},-1.2-15.74{ }^{\circ} \mathrm{C},-4.64-14.21{ }^{\circ} \mathrm{C}$, $-3.84-14.64{ }^{\circ} \mathrm{C}$ and $2.08-15.23^{\circ} \mathrm{C}$ respectively.

The mean temperature ranges for these data are - 0.74-17.10 ${ }^{\circ} \mathrm{C}, 2.07-19.19{ }^{\circ} \mathrm{C}, 1.32-19.04{ }^{\circ} \mathrm{C},-0.72-$ $17.53^{\circ} \mathrm{C}$ and $2.49-19.68^{\circ} \mathrm{C}$. Figure 10 shows the seasonal mean bias of all climatic data with monthly average CRU temperature data for all grids. All temperature data have less bias as compared to observation. ERA-Interim and CFSR have a very small bias compared to other data.

The seasonal and annual spatial distributions of the mean temperature biases have presented in Figs. 11 and 12. For MERRA the distribution of bias is between - 5.08-2.73 ${ }^{\circ} \mathrm{C}$ for all seasons. The bias of MERRA is warmer in the Western and North-Western parts of the Beas river basin $\left(>2{ }^{\circ} \mathrm{C}\right.$ during Winter) and cooler in other regions. ERA-Interim has a cooler bias for both seasonally and annually. The bias of ERA-Interim temperature for all seasons is between $-6.71-0.16{ }^{\circ} \mathrm{C}$. For 


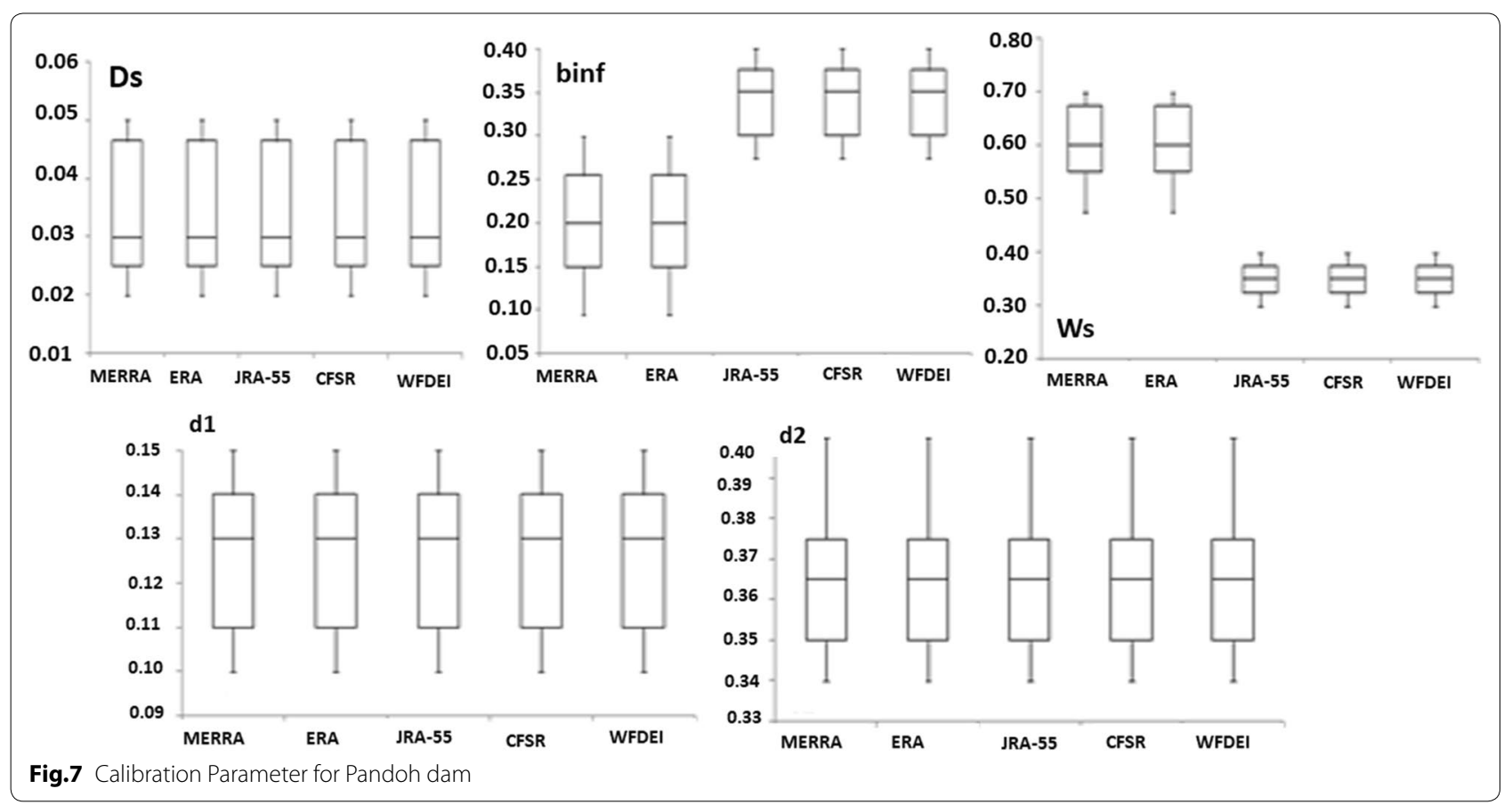

JRA-55 a warmer bias for all seasons exists at Western and North-Western Beas river basin. Whereas for Southern Beas JRA- 55 has a warmer bias $\left(>3^{\circ} \mathrm{C}\right)$ during Winter and post Winter seasons. Eastern and North-Eastern part of the basin have a cooler bias for all seasons. The bias variation for JRA- 55 is $-8.09-4.45{ }^{\circ} \mathrm{C}$ for all seasons. For CFSR during the post Winter and rainy season the SouthWestern part of Beas experience a warmer bias $\left(>2{ }^{\circ} \mathrm{C}\right)$. Except for Summer season the Western and North-Western part of river basin has a warmer bias. The bias distribution for CFSR for all seasons is $-9.39-2.45^{\circ} \mathrm{C}$. WFDEI agrees well with observed temperature $\left(-0.5-0.5{ }^{\circ} \mathrm{C}\right)$ for all seasons. During the Winter season a warmer bias of WFDEI exists for the whole river basin. During Summer and post-Monsoon season whole basin experience a cooler bias for WFDEI $\left(-0.54--0.05{ }^{\circ} \mathrm{C}\right)$. In Fig. 11 the spatial distribution of monthly temperature bias has presented. Figure 12 represents the annual temperature bias of the Beas river basin. For JRA-55 the middle portion of the Beas basin has a warmer bias $\left(0.50-1.40{ }^{\circ} \mathrm{C}\right)$ annually. The Eastern and North-Eastern portion of basin has a cooler bias for MERRA, JRA-55 and CFSR. For ERA-Interim a cooler bias observed for the whole basin $\left(-5.33\right.$ to $\left.-0.9{ }^{\circ} \mathrm{C}\right)$. WFDEI has a warmer bias for the entire basin. There is a variation of biases for different seasons and different reanalysis data.

Figure 12 also shows the correlations between the annual temperature of the various data for the period 1990-2009 and observations. The correlation of MERRA with observation is $>0.50$ for the whole basin. The spatial pattern of correlation at Western, North-Western and mid portion of the basin is similar for both ERA-Interim and JRA-55 reanalysis data $(>0.70)$. ERA-Interim has a higher correlation $(0.50-0.80)$ for all basin except a smaller portion of Southern basin $(-0.44)$. JRA-55 and CFSR have a small correlation in the North-Eastern part of the basin $(<0.30)$. However JRA-55, CFSR and WFDEI have correlation of $0.50-0.77,0.50-0.67$ and $0.52-0.77$ respectively for whole basin.

The RMSE value of WFDEI (Fig. 12) is less than other reanalysis products $\left(<0.50{ }^{\circ} \mathrm{C}\right)$. For CFSR the RMSE value is more for Eastern and North-Eastern parts of the Beas river basin $\left(4.34-8.96^{\circ} \mathrm{C}\right)$. The RMSE of JRA-55 is higher for the North-Western part of the basin $\left(5.79-6.90{ }^{\circ} \mathrm{C}\right)$. In other parts of the basin the RMSE value of JRA-55 is between $0.48-3.09{ }^{\circ} \mathrm{C}$. ERAInterim has RMSE value $3.61-5.07{ }^{\circ} \mathrm{C}$ in the NorthEast and Mid-East part of the Beas river basin. A lower RMSE value of ERA-Interim between $0.98-2.67{ }^{\circ} \mathrm{C}$ has observed in other portions of the basin. MERRA has RMSE $<5{ }^{\circ} \mathrm{C}$ for the entire basin.

\section{Comparison of modeled and observed rainfall products} MERRA, ERA-Interim, JRA-55, CFSR and WFDEI rainfall data have compared with observed rainfall data for raingauge stations Banjar, Bhuntar, Janjehal, Larji, Pandoh, Pong and Sainj. Figure 13 represents the average monthly rainfall variation for these five climatic products for the Beas river basin. MERRA, ERA-Interim, JRA-55, CFSR and WFDEI rainfall varies from 112.05-1307.19, 


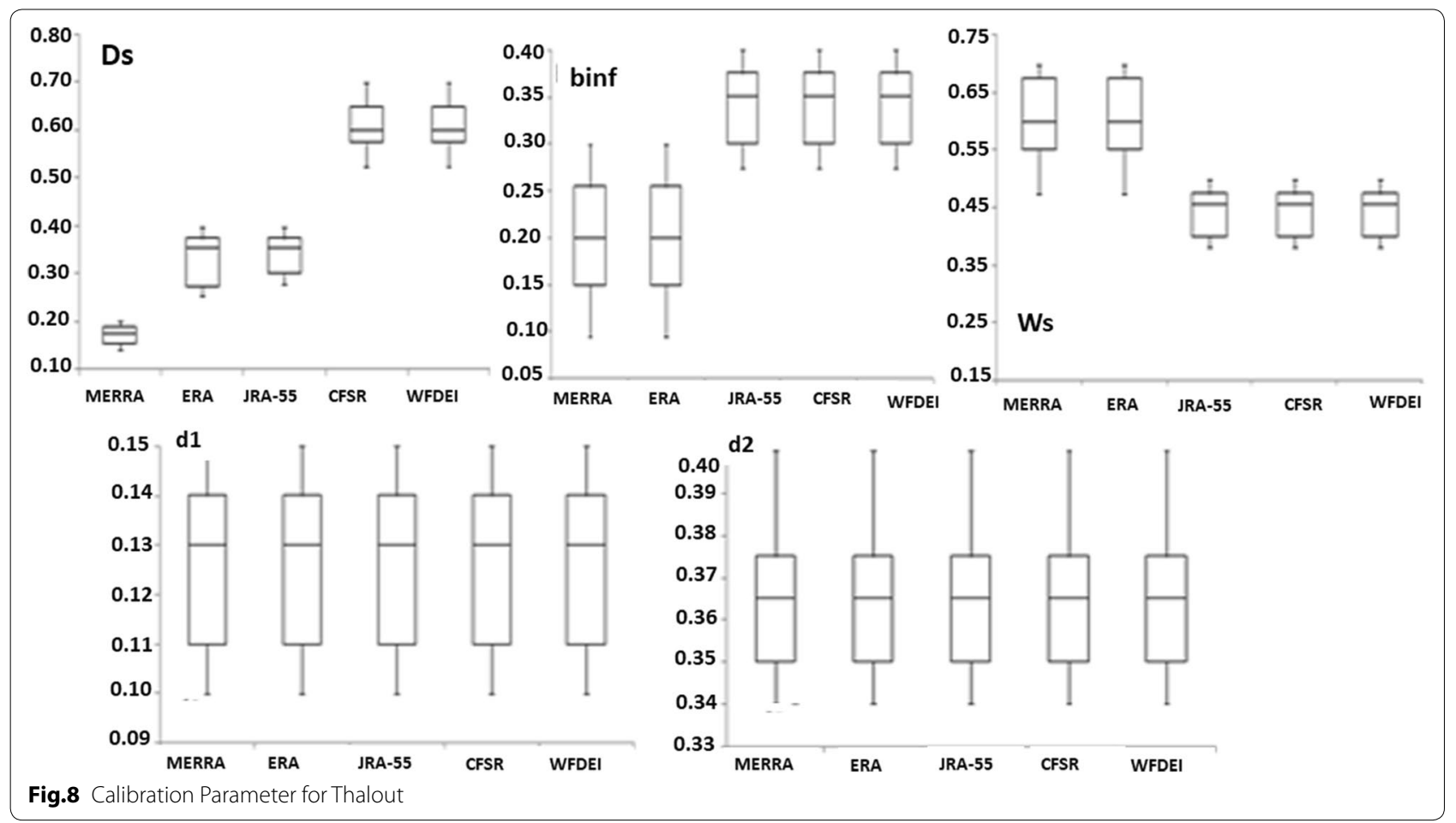

$33.89-1070.42,25.58-704.83,18.22-177.36$ and 12.37$207.70 \mathrm{~mm} / \mathrm{month}$. The average monthly rainfall of MERRA is higher followed by ERA-Interim, JRA-55, CFSR and WFDEI.

A comparison of mean monthly rainfall is presented in Fig. 14. All the rainfall products for all stations show a seasonal variation. However, MERRA followed by ERAInterim and JRA-55 highly overestimates observed rainfall for all stations. According to Fig. 16 the three rainfall products MERRA, ERA-Interim and JRA-55 overestimate the rainfall for the dry season. Because during December-February (Winter) and March-May (Summer) there is a high positive bias for these three rainfall estimates. The poor ability of reanalysis data to capture Summer convective precipitation for their spatial complexity is likely the main reason for overestimated Summer precipitation. Whereas the overestimated Winter precipitation is due to mismeasurement of snowfall by raingauges compared to liquid precipitation (Rasmussen et al. 2012; Goodison et al. 1998) or likely for non-raining clouds due to warm tropical convective systems (Ashouri et al. 2015). Hence Monsoon season generates a substantial bias. According to Bosilovich et al. (2008) the Monsoon season precipitation bias is likely for overestimated moisture content and observation system-generated precipitable water. The other season possesses a relatively low bias except MERRA in Banjar, Bhuntar, Larji and Sainj. However the MERRA rainfall bias for all stations is abnormally higher compared to other rainfall products for all seasons.

The mean annual comparison using statistical approaches has carried out in this study for modeled data with observed point rainfall data to quantify their performances. Pearson's correlation coefficient is used to evaluate how well the estimates correspond to the observed data. Table 2 showing the monthly statistical indicators to understand the performance of the reanalysis products for eight raingauge stations. CFSR and WFDEI have a very good correlation coefficient ranges 0.80 to 0.86 (except WFDEI at Banjar and CFSR at Pandoh (0.65)) as compared to MERRA, ERA-Interim and JRA-55. ERAInterim and JRA-55 have a moderate $R^{2}$ value that varies from $0.65-0.73$ next to CFSR and WFDEI except for ERA at Sainj (0.60). MERRA shows a lower $R^{2}$ value of $0.60-0.65$. All the reanalysis products correlate observed point rainfall data.

A higher bias and RMSE value have been observed for MERRA rainfall at a monthly scale compared to other rainfall estimates for all stations. Next to MERRA, ERAInterim and JRA-55 also possesses a higher RMSE for all stations. The CFSR and WFDEI data have low RMSE (15-50 mm month ${ }^{-1}$ ) as compared to other products. 


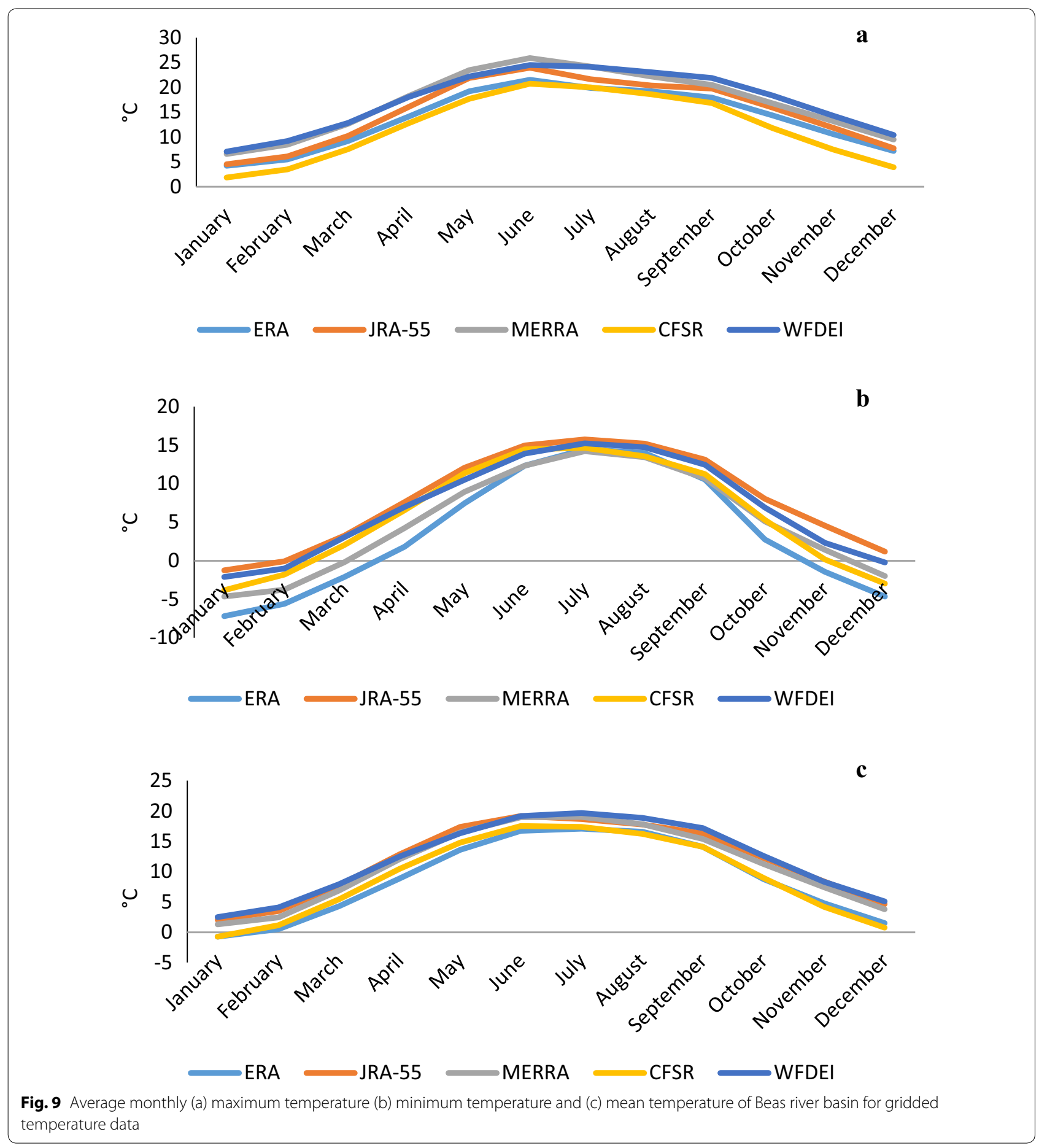

ERA-Interim precipitation has significantly higher overestimation next to MERRA. Overestimation of JRA-55 rainfall also observed next to ERA-Interim. However the underestimation (negative bias) of CFSR and WFDEI precipitation has found when compared with observation.

\section{Simulation of monthly streamflow}

In this study the Variable Infiltration Capacity hydrology model has been used to compare streamflow from observed, reanalysis and global meteorological data after finding overestimation/underestimation of reanalysis 


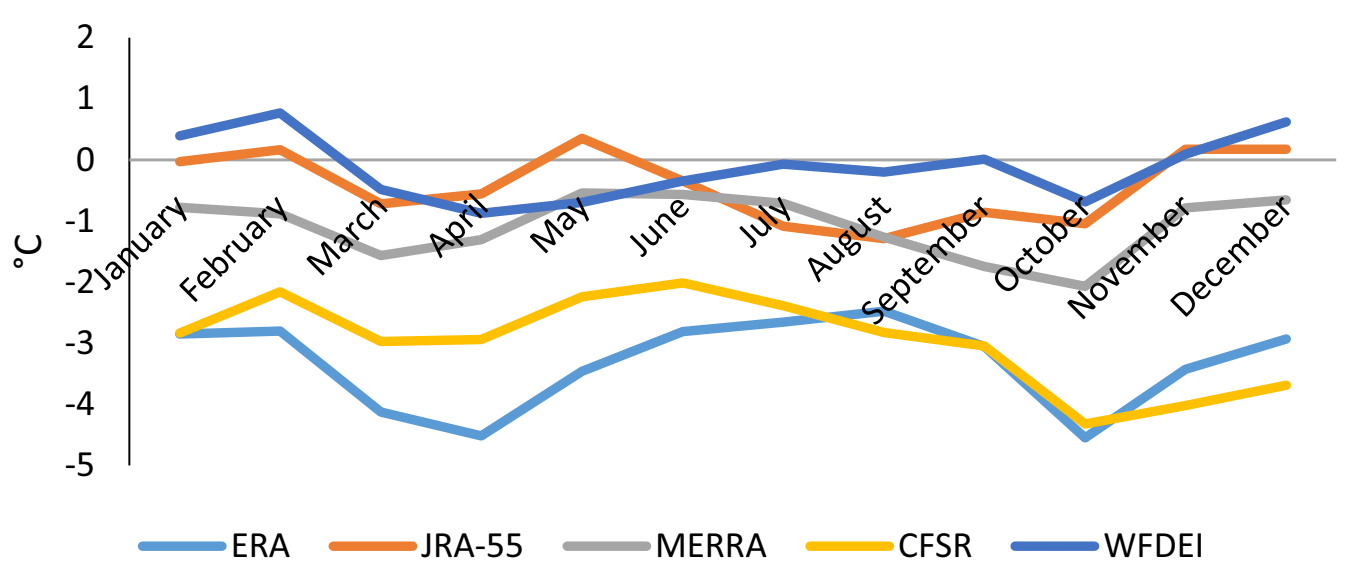

Fig. 10 Average monthly bias of mean temperature of Beas river basin for gridded and CRU temperature dataset

products compared to observations. The ERA-Interim temperature data has used as meteorological input along with rainfall data from different reanalysis products for VIC hydrology model. The monthly simulation comparison results of streamflow for observed, reanalysis and the global meteorological products at Manali, Thalout, Pong dam and Pandoh dam are presented in Figs. 17, 18, 19 and 20. The calibration period for Manali, Thalout, Pong dam and Pandoh dam are 1994-1999, 1993-1997, 1992-1997 and 1994-1999. Whereas the period of validation for the above-mentioned stations are 2003-2009, 1999-2005, 2000-2009 and 2003-2009 respectively. The accepted value for NSE is considered as 0.6 (Essou et al. 2016a, b). According to Moriasi et al. (2007) the model performance is very good when PBIAS $< \pm 10$, good when $\pm 10 \leq$ PBIAS $\leq \pm 15$, satisfactory when $\pm 15 \leq$ PBIAS $\leq \pm 25$ and unsatisfactory when PBIAS $> \pm 25$. If $R^{2}$ considered alone for model evaluation criteria the major drawback is dispersion is quantified. Even the model underpredict or overpredict systematically the $R^{2}$ value still results in very good and close to 1 (Krause et al. 2005). Thus NSE is better than $R^{2}$ for model evaluation. After comparing all model performance criteria (Table 3) it has observed that the model performance is not good for the Pong dam due to reservoir regulation impact on streamflow. The NSE and PBIAS range from $-2.30-0.30$ and $82.47-26.34 \%$ for all reanalysis estimates. The RMSE value at Pong dam is also high compared to other discharge stations (98.92-265.31) during both calibration and validation. Therefore the performance of different reanalysis data has been evaluated for three discharge stations Pandoh dam, Manali and Thalout. MERRA overestimates the streamflow for the these three locations during the simulation period. The PBIAS ranges from $26-65 \%$. During the simulation period (0.46-0.70), the NSE value indicates the unsatisfactory performance of MERRA for the Beas. JRA-55 underestimates observed streamflow for the entire simulation period. The reanalysis is also not able to properly follow the observed hydrograph pattern. The reason may be the dataset fails to reproduce spatial pattern precipitation for the Beas river basin. However it tends to follow the low flow pattern of observed hydrograph with slight underestimation. For Pandoh dam slight overestimation of low flow observed for JRA-55. The performance of JRA-55 also not acceptable in terms of NSE $(0.10-0.44)$ and PBIAS ( -50.00 to $-11.00 \%)$. CFSR and WFDEI heavily underestimate the streamflow (peak and low flow) for simulation. The model performances using these reanalysis products are not good due to poor quality rainfall estimates. The NSE and PBIAS values are inferior for these two products when compared to observed streamflow. The NSE and PBIAS for CFSR ranges $-0.65-0.13$ and -80.87 to $-56.74 \%$. Whereas for WFDEI the value of NSE and PBIAS varies from -1.16 to -0.17 and -93.75 to $-82.00 \%$. The JRA -55 , CFSR and WFDEI also have less ability to produce peak flow during Monsoon. Figure 15 also indicates that JRA55, CFSR and WFDEI data have poor seaonal cycles and miss most of the peak during Monsoon season. A good performance of the ERA-Interim dataset observed for the study basin for the whole simulation period. The NSE (0.73-0.77) and PBIAS ( -13.68 to 18.00 ) value indicate a good match of modeled and simulated flow using the ERA-Interim data. However the RMSE value of ERAInterim is less as compared to other reanalysis products. Additionally ERA-Interim data follows the hydrograph pattern properly (High flow and low flow). ERA-Interim is also able to simulate high peak of streamflow for all stations as compared to other rainfall products. However 


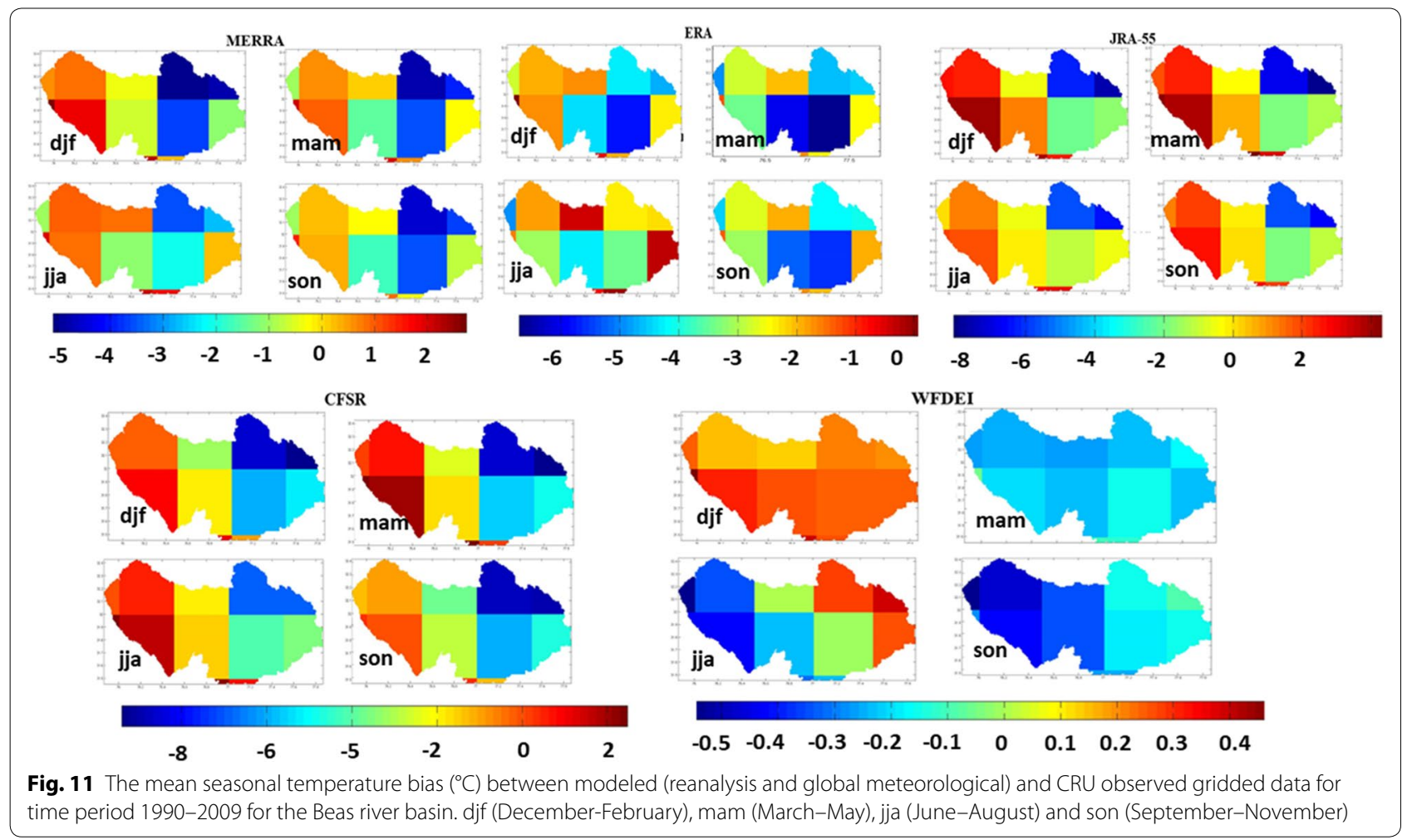

overestimation of low flow for ERA-Interim observed for Thalout and Pandoh dam. The RMSE value at Manali is less than other portions of the basin for all products.

\section{Discussions}

Temperature and precipitation from four reanalysis and global meteorological data are evaluated to examine their perspective to use as a substitute of observation. From the result it has observed that there is a good similarity exists between reanalysis temperature products and observed temperature. There is also no high variation of temperature has observed between all reanalysis data. The radiosondes and satellite derived atmospheric temperature products have regularly assimilated with the reanalysis system which is the main reason for their good association with observed temperature (Essou et al. 2016a, b). However the seasonal and annual bias of temperature is high at the Western and North-Western portion of the Beas river basin for all reanalysis products. In contrast the Eastern and North-Eastern part of the basin has a cooler bias. The reason for differences between various reanalysis temperatures is the variability of land-atmosphere interaction and land surface scheme. Different SST (Sea surface temperature) datasets used in reanalysis data can be responsible for their discrepancy to some extent (Shah and Mishra 2014). The observed temperature pattern better represented by ERA-Interim regarding bias, RMSE and correlation which resembles the findings of Shah and Mishra (2014). Due to scarcity of direct snow measurement in snow/glacier covered Eastern Beas the reanalysis temperature can also be a useful data source for estimating snowmelt runoff by energy balance based VIC hydrology model.

In data-scarce basin like Beas there is uncertainty in getting high quality of observed rainfall data (Rolland 2003). The reason is the irregular distribution of weather stations, cold weather terrain, wind and massive snowfall. According to Barros et al. (2004) in the Himalayan region like Beas precipitation varies between valleys and ridges. So, the variability at the scale of kilometers cannot be determined by a single raingauge station. There is a considerable difference when station rainguage data have compared with the associated pixel value of modeled gridded rainfall data. The non-availability of raingauge stations at high elevation can also cause underestimated precipitation at highland. Because of this there is a high need to investigate grid-based high-resolution reanalysis rainfall data as a substitute of point raingauge data for the Beas river basin. In this study MERRA, ERA-Interim, JRA-55, CFSR and WFDEI rainfall data have compared with point rainguage data for a long term basis. All the rainfall data have correlated observed rainfall in terms of $\mathrm{R}^{2}$ and NSE. CFSR and WFDEI reanalysis data underestimate observed rainfall due to the uncertainty of these 


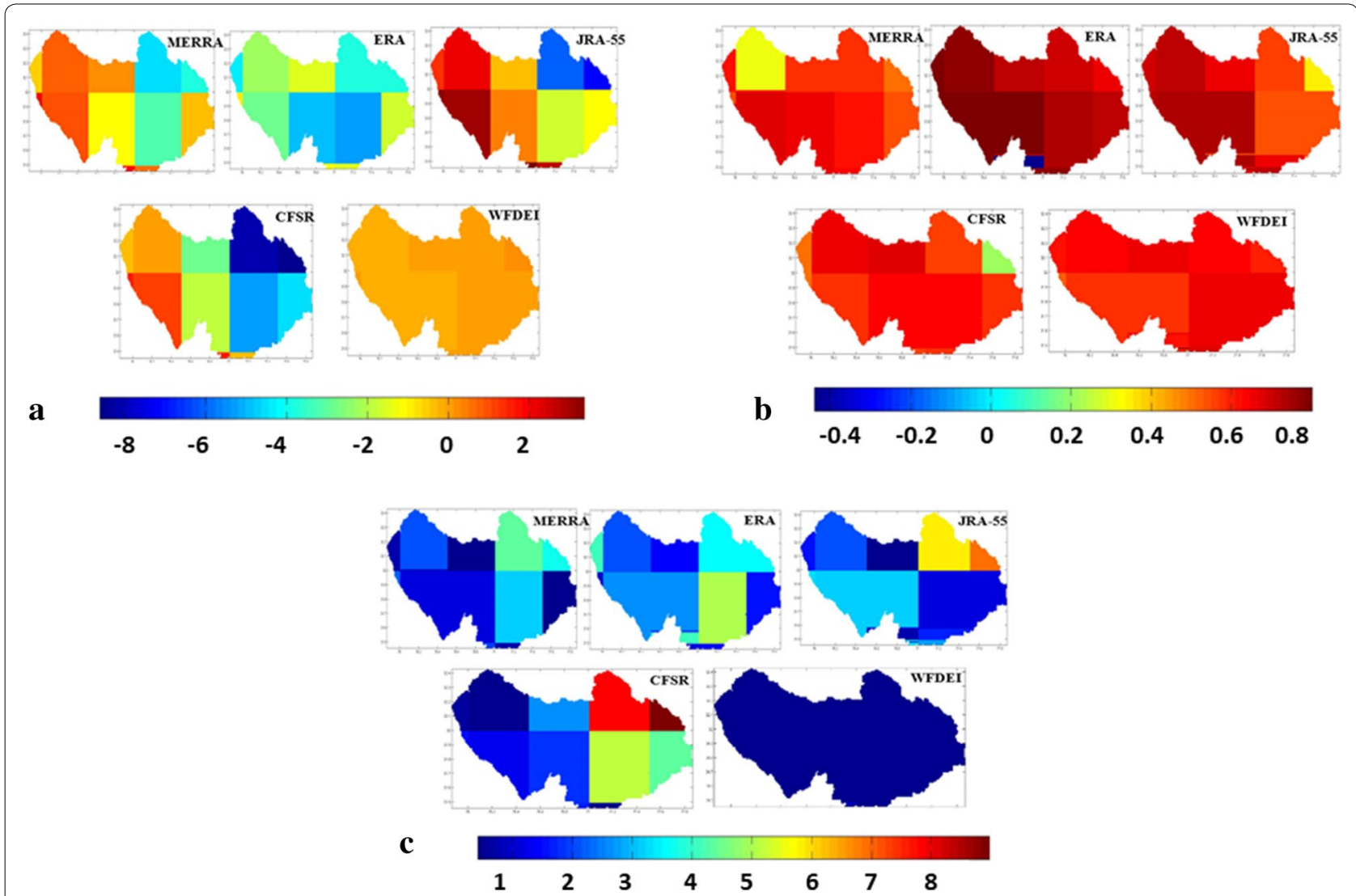

Fig. 12 The annual temperature $(\mathbf{a})$ bias $\left({ }^{\circ} \mathrm{C}\right)$ (b) correlation (c) RMSE (Root Mean Square Error) between modeled (reanalysis and global meteorological) and CRU observed gridded data for time period 1990-2009

data. MERRA, ERA-Interim and JRA-55 overestimate observed rainfall. All the reanalysis and global meteorological estimates have a high spatial resolution. The inconsistency of spatial scale between grid-cell average value and observed data of raingauge stations could cause some degree of overestimation or underestimation of these coarse resolution reanalysis products (Maraun 2013). The interpolation of MERRA, ERA-Interim and JRA-55 rainfall data to 0.5-degree spatial resolution can also induce error to the outcome which affects the validation result. The higher RMSE value for MERRA, ERAInterim and JRA-55 reanalysis products may be due to

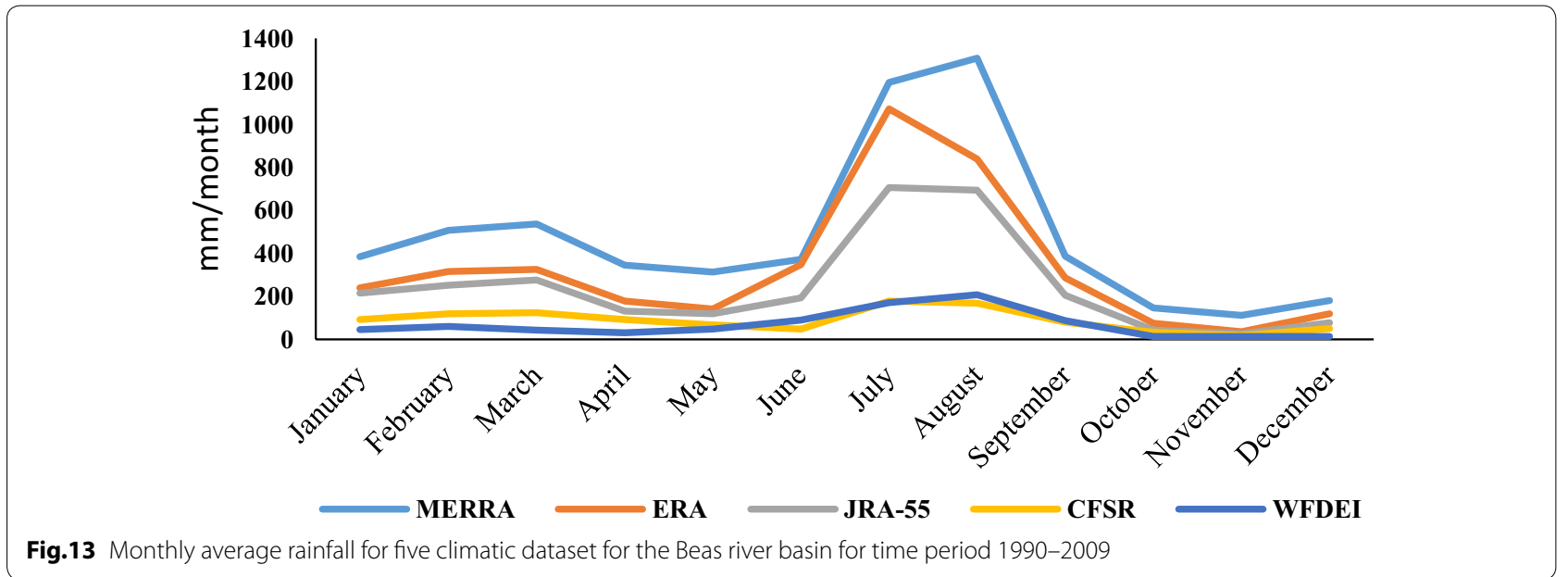




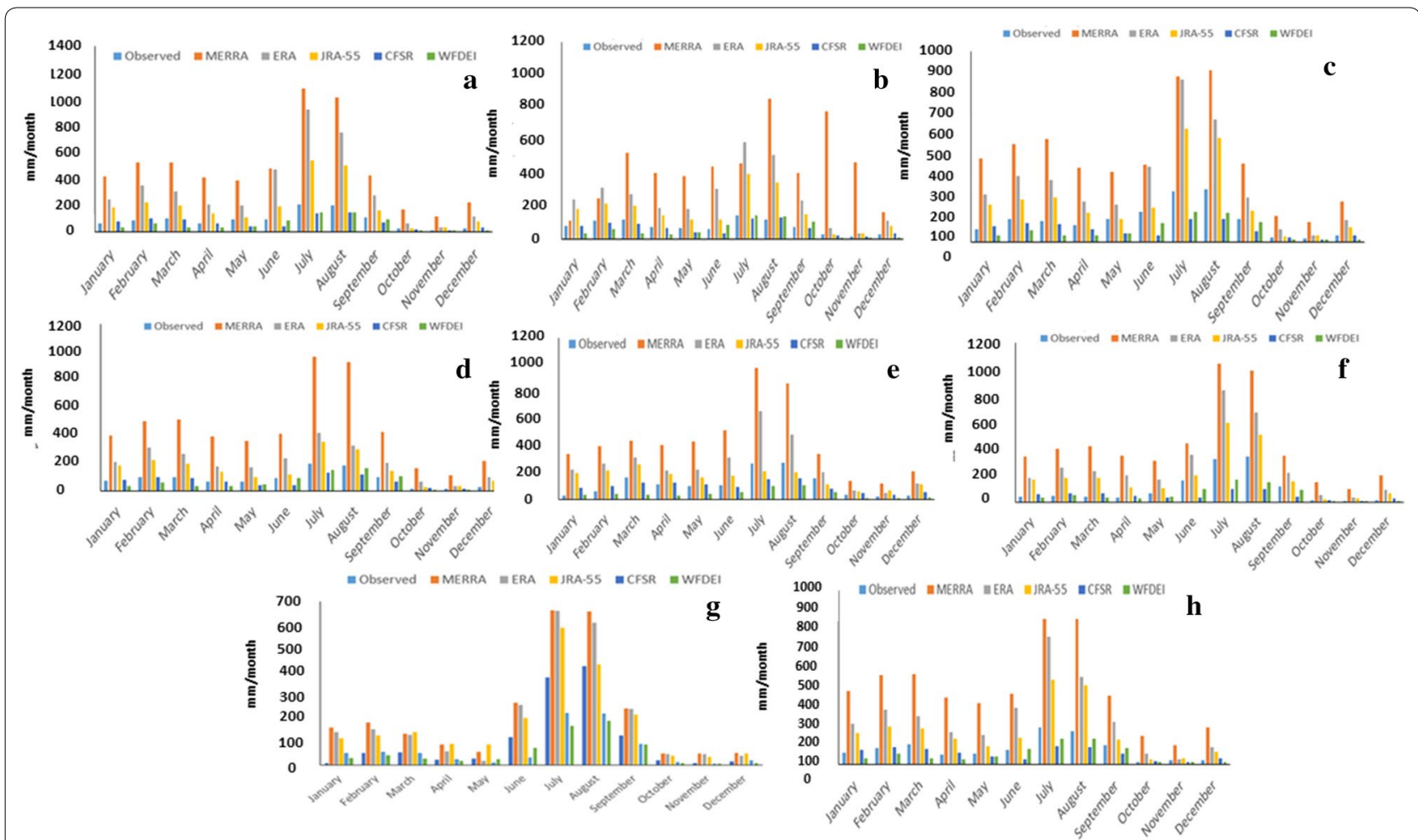

Fig.14 Comparison of average monthly rainfall patterns (1990-2009) at different stations of the Beas river basin (a) Banjar (b) Bhuntar (c) Janjehal (d) Larji (e) Manali (f) Pandoh (g) Pong and (h) Sainj from different rainfall data at the Beas river basin

sensitivity of RMSE to heavy convective and local precipitation events in high altitude Beas river basin. Whole pixel estimation of rainfall during localized precipitation events can also cause error in gridded reanalysis products. Due to complex topography and high spatio-temporal variability of rainfall the straight comparison of different reanalysis and global meteorological products upon raingauge is not possible for the Beas river basin. As a result the simulated discharge of the VIC hydrology model has been evaluated in this research to indirectly review the quality of these reanalysis estimates to reflect topographical complexity of rainfall. The capability of these reanalysis data to capture the magnitude of mountain rainfall patterns also have evaluated through the modeling approach. The non-bias corrected rainfall data has used as hydrology input due to the poor quality of rainguage data. According to Essou et al. (2016a, b) the bias correction of reanalysis data with observation could introduce additional error in reanalysis data in datascarce mountain region. The result of the study brings out the difference in skill between different reanalysis data to reproduce orographic rainfall.

1. MERRA overestimates the observed raingauge data (Figs. 14, 16). The coarse resolution reanalysis also overestimates discharge when applied to the hydrology model (Figs. 17, 18, 19, 20). The reason is the dependability of the reanalysis data on the weather forecast model's mechanic to simulate precipitation and not to assimilate surface precipitation data (Essou et al. 2016a, b). Due to limited ground observation the assimilation system of MERRA faces problems due to tropical continental precipitation. Another major reason for it's recovery of performance over land is cloudy conditions. The reanalysis data is also unable to properly parameterize landatmosphere interactions (Blacutt et al. 2015). Therefore the higher uncertainty exists between observed and MERRA precipitation.

2. Next to MERRA a higher bias of ERA-Interim rainfall has observed upon raingauge data (Figs. 14, 16). For coarse resolution reanalysis products like MERRA, ERA-Interim and JRA-55 the high precipitation likely comes from parameterized convection. The other reason may be the assimilation of a limited set of observations and limitation of parameterization during the process of precipitation generation (Beck et al. 2018). ERA-Interim uses less surface observations as compared to JRA-55, CFSR and WFDEI reanalysis data. Shah and Mishra (2014) and 
Table 2 Summary of the monthly statistical indicators

\begin{tabular}{|c|c|c|c|c|c|c|}
\hline Stations & Statistical parameter & MERRA & ERA-Interim & JRA-55 & CFSR & WFDEI \\
\hline \multirow[t]{4}{*}{ Banjar } & $R^{2}$ & 0.65 & 0.68 & 0.70 & 0.70 & 0.65 \\
\hline & $\operatorname{BIAS}(\%)$ & 423.28 & 260.62 & 117.21 & -21.76 & -33.59 \\
\hline & RMSE & 250.12 & 229.86 & 122.04 & 40.00 & 25.34 \\
\hline & $\mathrm{R}$ & 0.60 & 0.79 & 0.82 & 0.80 & 0.79 \\
\hline \multirow[t]{4}{*}{ Bhuntar } & $R^{2}$ & 0.65 & 0.68 & 0.65 & 0.70 & 0.70 \\
\hline & $\operatorname{BIAS}(\%)$ & 496.83 & 224.20 & 110.89 & -14.36 & -26.80 \\
\hline & RMSE & 372.83 & 173.26 & 91.12 & 15.81 & 21.23 \\
\hline & $\mathrm{R}$ & 0.75 & 0.80 & 0.78 & 0.81 & 0.82 \\
\hline \multirow[t]{4}{*}{ Janjehal } & $R^{2}$ & 0.63 & 0.68 & 0.70 & 0.75 & 0.70 \\
\hline & $\operatorname{BIAS}(\%)$ & 270.11 & 157.87 & 78.83 & -45.37 & -47.06 \\
\hline & RMSE & 317.05 & 184.70 & 98.00 & 52.13 & 52.20 \\
\hline & $\mathrm{R}$ & 0.75 & 0.81 & 0.81 & 0.85 & 0.82 \\
\hline \multirow[t]{4}{*}{ Larji } & $R^{2}$ & 0.60 & 0.70 & 0.68 & 0.70 & 0.70 \\
\hline & $\operatorname{BIAS}(\%)$ & 418.44 & 139.41 & 78.41 & -22.08 & -34.94 \\
\hline & RMSE & 349.78 & 125.15 & 71.73 & 23.00 & 30.20 \\
\hline & $\mathrm{R}$ & 0.75 & 0.83 & 0.80 & 0.82 & 0.83 \\
\hline \multirow[t]{4}{*}{ Manali } & $R^{2}$ & 0.60 & 0.70 & 0.68 & 0.70 & 0.70 \\
\hline & BIAS(\%) & 292.48 & 127.27 & 42.25 & -14.37 & -64.47 \\
\hline & RMSE & 305.09 & 150.34 & 64.70 & 30.20 & 70.07 \\
\hline & $\mathrm{R}$ & 0.73 & 0.82 & 0.81 & 0.82 & 0.82 \\
\hline \multirow[t]{4}{*}{ Pandoh } & $R^{2}$ & 0.60 & 0.68 & 0.65 & 0.65 & 0.70 \\
\hline & $\operatorname{BIAS}(\%)$ & 306.98 & 170.02 & 91.72 & -52.20 & -45.15 \\
\hline & RMSE & 309.67 & 185.13 & 99.68 & 50.07 & 41.70 \\
\hline & R & 0.75 & 0.82 & 0.80 & 0.80 & 0.82 \\
\hline \multirow[t]{4}{*}{ Pong } & $R^{2}$ & 0.65 & 0.70 & 0.70 & 0.70 & 0.75 \\
\hline & BIAS(\%) & 104.03 & 90.49 & 50.56 & -39.96 & -52.07 \\
\hline & RMSE & 109.60 & 56.21 & 105.09 & 44.85 & 54.00 \\
\hline & R & 0.80 & 0.84 & 0.82 & 0.80 & 0.86 \\
\hline \multirow[t]{4}{*}{ Sainj } & $R^{2}$ & 0.65 & 0.60 & 0.73 & 0.75 & 0.70 \\
\hline & $\operatorname{BIAS}(\%)$ & 396.81 & 197.05 & 107.11 & -32.91 & -34.76 \\
\hline & RMSE & 350.00 & 185.23 & 111.70 & 30.26 & 29.87 \\
\hline & R & 0.76 & 0.75 & 0.70 & 0.86 & 0.80 \\
\hline
\end{tabular}

Ghodichore et al. (2018) have also found the overestimated precipitation of ERA-Interim in North India as compared to observation. Hence, the satisfactory result has been obtained after simulation of the model by ERA-Interim as it tends to follow the hydrograph pattern of observed streamflow regarding other products (Figs. 17, 18, 19, 20). The performance of ERA-Interim is also acceptable in terms of statistical parameters NSE, PBIAS and RMSE during both calibration and validation periods. The reanalysis performs well in streamflow simulation for complex terrain of Manali where reliable snowfall measurement is tough for gridded rainfall products. This proves that ERA-Interim reanalysis better represents kinetic precipitation of the Beas river basin. Bhattacharya et al. (2019) also found that the rainfall gradient of ERA-Interim is linearly correlated with altitude. The reason may be the ERA-Interim reanalysis product uses a four-dimensional variational (4D-var) analysis model. The 4D-var is automatically adjusted to the bias of satellite observation of radiance, modifies convective and boundary layer cloud schemes, increases the stability of the atmosphere and produces a small amount of rainfall (Dee et al. 2011). Additionally observations are more effectively used by 4D-var due to the extraction of details of mass field trends (Rabier et al. 1998, 2000). The ERAInterim also formulate a background error problem, improve the physical model and perform better in simulating various land surface schemes (Simmons et al. 2010; Olauson 2018). 
Table 3 Statistical indicators during calibration and validation at monthly scale (1990-2009)

\begin{tabular}{|c|c|c|c|c|c|}
\hline \multirow[t]{2}{*}{ Stations } & \multirow[t]{2}{*}{ Statistical parameter } & \multicolumn{4}{|l|}{ Stations } \\
\hline & & Manali & Thalout & Pong & Pandoh \\
\hline \multicolumn{6}{|l|}{ MERRA } \\
\hline \multirow[t]{4}{*}{ Calibration } & $R^{2}$ & 0.75 & 0.70 & 0.56 & 0.68 \\
\hline & NSE & 0.70 & 0.55 & -0.21 & 0.61 \\
\hline & PBIAS (\%) & 26.00 & 30.00 & 26.34 & 52.00 \\
\hline & RMSE & 13.29 & 152.00 & 161.09 & 109.78 \\
\hline \multirow[t]{4}{*}{ Validation } & $\mathrm{R}^{2}$ & 0.69 & 0.71 & 0.30 & 0.75 \\
\hline & NSE & 0.46 & 0.55 & 0.20 & 0.52 \\
\hline & PBIAS (\%) & 30.00 & 30.00 & 1.16 & 65.00 \\
\hline & RMSE & 16.40 & 100.00 & 101.11 & 92.65 \\
\hline \multicolumn{6}{|l|}{ ERA-Interim } \\
\hline \multirow[t]{4}{*}{ Calibration } & $R^{2}$ & 0.73 & 0.74 & 0.60 & 0.75 \\
\hline & NSE & 0.76 & 0.76 & 0.30 & 0.76 \\
\hline & PBIAS (\%) & -13.78 & -13.78 & 1.44 & 15.00 \\
\hline & RMSE & 8.00 & 70.45 & 109.87 & 78.50 \\
\hline \multirow[t]{4}{*}{ Validation } & $R^{2}$ & 0.74 & 0.73 & 0.35 & 0.72 \\
\hline & NSE & 0.77 & 0.75 & 0.21 & 0.73 \\
\hline & PBIAS (\%) & -13.68 & -14.54 & -10.00 & 18.00 \\
\hline & RMSE & 8.00 & 65.75 & 98.92 & 60.76 \\
\hline \multicolumn{6}{|l|}{ JRA-55 } \\
\hline \multirow[t]{4}{*}{ Calibration } & $R^{2}$ & 0.58 & 0.62 & 0.42 & 0.63 \\
\hline & NSE & 0.10 & 0.32 & -0.12 & 0.34 \\
\hline & PBIAS (\%) & -50.00 & -36.75 & -30.67 & -32.78 \\
\hline & RMSE & 26.40 & 139.85 & 155.19 & 132.00 \\
\hline \multirow[t]{4}{*}{ Validation } & $R^{2}$ & 0.50 & 0.60 & 0.45 & 0.53 \\
\hline & NSE & 0.30 & 0.21 & -0.40 & 0.44 \\
\hline & PBIAS (\%) & -38.00 & -42.00 & -39.00 & -11.00 \\
\hline & RMSE & 22.54 & 138.00 & 120.11 & 95.00 \\
\hline \multicolumn{6}{|l|}{ CFSR } \\
\hline \multirow[t]{4}{*}{ Calibration } & $R^{2}$ & 0.41 & 0.50 & 0.22 & 0.51 \\
\hline & NSE & -0.65 & -0.51 & -1.10 & 0.05 \\
\hline & PBIAS (\%) & -80.87 & -75.43 & -56.37 & -64.00 \\
\hline & RMSE & 34.08 & 210.34 & 220.45 & 171.24 \\
\hline \multirow[t]{4}{*}{ Validation } & $R^{2}$ & 0.38 & 0.53 & 0.14 & 0.47 \\
\hline & NSE & -0.64 & -0.65 & -2.00 & 0.13 \\
\hline & PBIAS (\%) & -76.76 & -80.00 & -68.26 & -56.74 \\
\hline & RMSE & 30.59 & 190.65 & 199.10 & 121.23 \\
\hline \multicolumn{6}{|l|}{ WFDEI } \\
\hline \multirow[t]{4}{*}{ Calibration } & $R^{2}$ & 0.36 & 0.43 & 0.15 & 0.43 \\
\hline & NSE & -1.00 & -0.30 & -2.15 & -0.23 \\
\hline & PBIAS (\%) & -93.73 & -85.69 & -78.00 & -82.00 \\
\hline & RMSE & 38.01 & 218.56 & 265.31 & 186.24 \\
\hline \multirow[t]{4}{*}{ Validation } & $R^{2}$ & 0.28 & 0.42 & 0.12 & 0.36 \\
\hline & NSE & -1.16 & -0.40 & -2.30 & -0.17 \\
\hline & PBIAS (\%) & -93.75 & -87.76 & -82.47 & -82.16 \\
\hline & RMSE & 32.56 & 209.97 & 233.64 & 137.78 \\
\hline
\end{tabular}




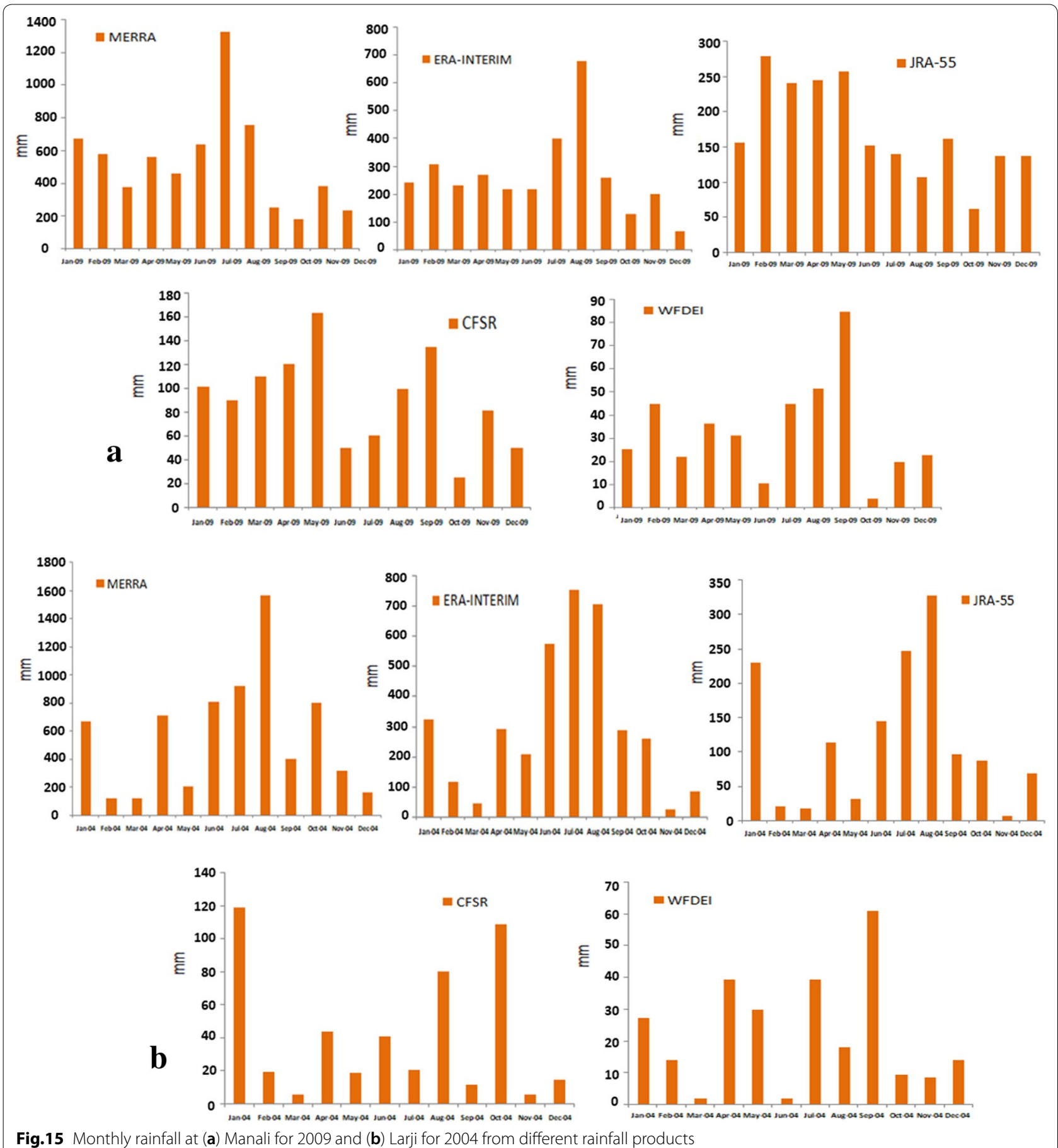

3. Instead of using merged precipitation from the observed station during assimilation, the overestimation of JRA-55 precipitation (compared to raingauge stations) happens due to excess rainfall after the beginning of forecasts (Figs. 14, 16) due spin-down problem, dry bias in tropical Beas (Kobayashi et al.
2015), convective scheme (Arakawa and Schubert 1974) adopted by JRA-55 and implementing convection-triggering mechanism (DCAPE) which generates higher rainfall. Ghodichore et al. (2018) found overestimated JRA-55 compared to observation in North India. Hence the underestimation of stream- 
flow has observed for JRA-55 during the simulation period (Figs. 17, 18, 19, 20). The reanalysis data is also weak in following the observed hydrograph pattern. JRA-55 incorporates advanced features like, 4D-var during assimilation, improved bias-correction method for satellite data, high-resolution of model and integration of several observed data (Kobayashi 2020). Still the poor ability of the reanalysis to reproduce interannual variability of Beas rainfall may be due to error induced during bias-correction for observed data. Less dense and poor quality of observed data used in the bias-correction algorithm is the main cause of such errors (Essou et al. 2016a, b; Kobayashi 2020). The other reasons for inaccuracy of the reanalysis products are uncertainty of model and alteration of the observing system. Therefore serious attention is needed to apply JRA-55 rainfall (Bosilovich et al. 2011; Trenberth et al. 2011) for hydrology modeling.

4. CFSR rainfall underestimates the rainguage data (Figs. 14, 16). The reanalysis product also heavily underestimates the observed hydrograph (Figs. 17, 18, 19, 20). Shah and Mishra (2014) have a similar finding of underestimated CFSR rainfall in the North-Western region of India. Further the rainfall estimate fails to reproduce the Summer and Winter hydrograph pattern due to the variability of rainfall. CFSR uses three-dimensional variational data assimilation (3D-var) scheme, assimilate satellite radiance, use automated variational scheme for bias-correction of satellite radiances and generates precipitation field by observed rainguage data (Saha et al. 2010; Wang et al. 2011; Xie et al. 2007). The weak spatial distribution of CFSR rainfall and hydrology model uncertainty may cause by assimilated poor quality raingauge data (Kobayashi et al. 2015). The other reasons for the inferior data may be error involved in the algorithm for combining several observed rainfall data, bias-correction error and error due to the specific algorithm from observation operator during estimation of precipitation (Janjic et al. 2017; Shen et al. 2010).

5. Like the CFSR, WFDEI data underestimate both rainguage and discharge data (Figs. 14, 16, 17, 18, 19, $20)$. The reanalysis is also not able to accurately simulate the temporal streamflow pattern. WFDEI uses CRU/GPCC observed data to correct ERA-Interim reanalysis for precipitation bias (Weedon et al. 2014). The bias-correction of WFDEI with CRU observed data intruse error in the data. The CRU data uses only a portion of all rainguages (old observation data located at valley floor) which is unable to represent the orographic rainfall pattern leads to improper precipitation phase of WFDEI (Beck et al. 2017b, a; Weedon et al. 2014; Li et al. 2013).

The result of the study reveals that the performances of MERRA, JRA-55, CFSR and WFDEI are not good in Beas due to their dependency on altitude. Essou et al. (2016a, b) have reported that the inferior standard of reanalysis products in producing an adequate simulation of streamflow in the subtropical Beas river basin is may be due to non-uniform distribution of precipitation, sensitivity to daily precipitation for seasonality, weak mean annual cycle and poor simulation ability of local events, i.e. convective storm during Summer. Sun et al. (2018) have found overestimated precipitation of MERRA and ERA-Interim at high elevation as compared to observation, higher precipitation of JRA-55 at tropical regions, poor ability of reanalysis products in estimating orographic precipitation and higher interannual variability of Monsoon season precipitation. Additionally Ghodichore et al. (2018) have compared NCEP/NCAR, CFSR, ERA-Interim, MERRA and JRA-55 reanalysis products for India. The study finds notable seasonal and regional differences exist between reanalysis and observed rainfall data in the complex data-scarce mountain region. In this study ERA-Interim has found to be best among all reanalysis products. The other researchers (Essou et al. 2016b, 2017; Beck et al. 2017a; Sun et al. 2018) also found the superior performance of ERA-Interim in the data-scarce region. The adjustment of model calibration parameters in this study has done so that model results consistently come close to observed data. However the parameters adjusted during the calibration period to increase or decrease discharge cannot substantially improve streamflow for poor-performing reanalysis products. Oudin et al. (2006) have reported that modified calibration parameters have a little influence to compensate misrepresentation of streamflow due to precipitation. According to various studies (Fu et al. 2011; Nkiaka et al. 2017) for catchment areas larger than $1000 \mathrm{Km}^{2}$ the rainfall data from large area smooths the spatial resolution effect on streamflow. So, there is an insignificant impact of rainfall spatial resolution on streamflow for the Beas river basin (catchment area 12,417 $\mathrm{km}^{2}$ ). The improvement of Beas streamflow totally depends on the ability of reanalysis products to produce accurate precipitation. Many studies also have proved the uncertainty in simulated streamflow may be due to input precipitation error (Hong et al. 2006; Moulin et al. 2009). In this research VIC hydrology model shows it's potential to indirectly differentiate various reanalysis rainfall products by simulated streamflow. 


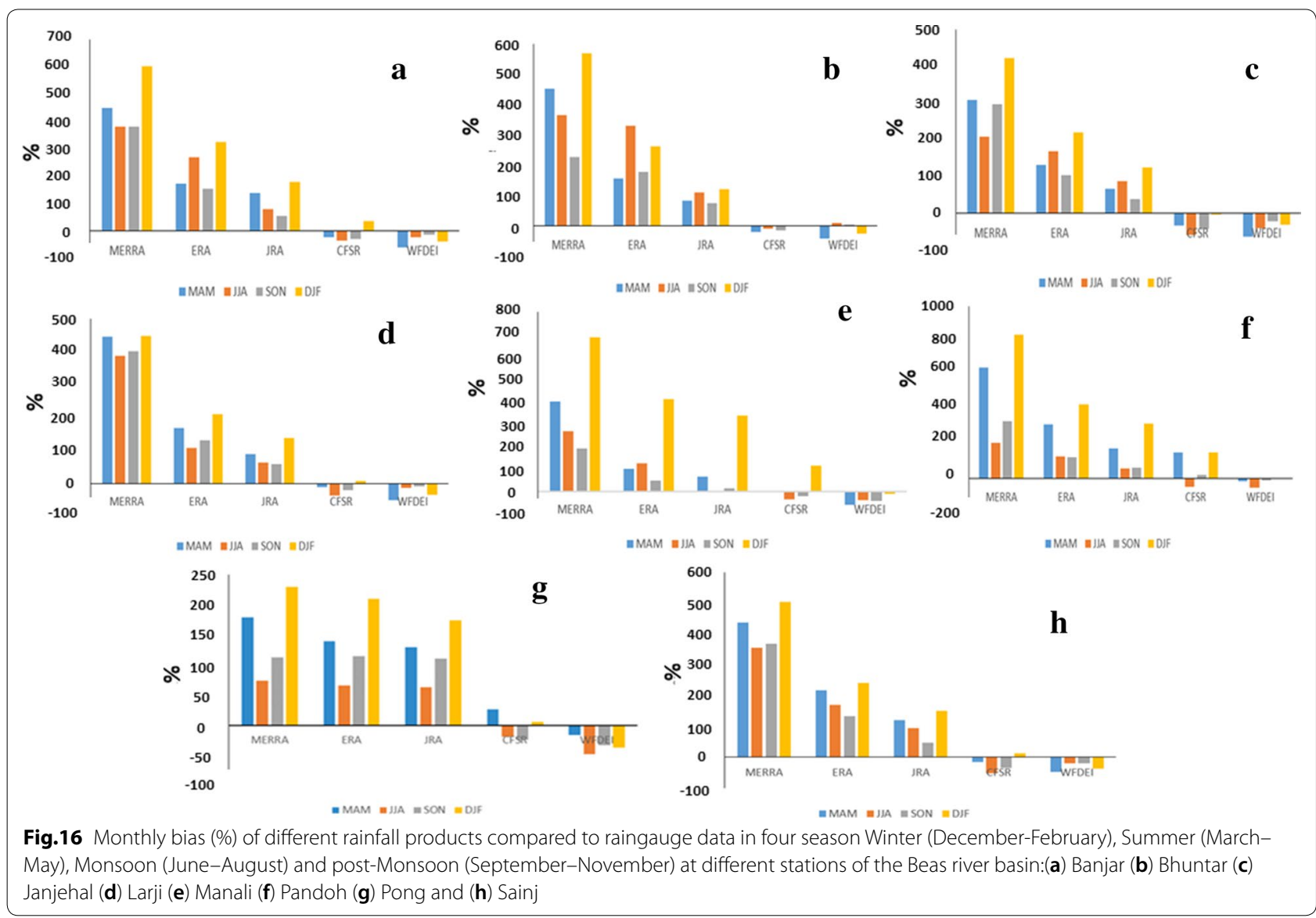

\section{Conclusions}

The inferior quality of observed rainfall data is the main reason for poor simulated discharge in data-scarce and topographically complex Beas river basin. Observed rainfall inherent some uncertainty due to measurement error. In this study observed station rainfall and temperature data are compared with different reanalysis and global meteorological data. The spatio-temporal variability of various modeled climate data is also compared by simulated streamflow accuracy of the VIC hydrology model. The comparison of various reanalysis, global meteorological and station data in Beas has been conducted to find out reliable climate data as a proxy of observations and to find out the similarity and inconsistency between various datasets. The performance evaluation of various precipitation and temperature products has done at monthly and annual basis and based on statistical metrics. The study revealed a good correlation between reanalysis and observed temperature data. The gridded reanalysis temperature better represent snowmelt runoff in data-scarce snow/glacier covered Eastern Beas. Weak performance of reanalysis rainfall data as rainfall-runoff input has observed as compared to temperature in this study. All modeled rainfall data show a considerable difference when compared with observed data. JRA-55, CFSR and WFDEI are also not able to reproduce the observed hydrograph pattern accurately. MERRA overestimates station rainfall and observed discharge data due to error in model operation and not including observed precipitation data during assimilation. The performance of JRA-55, CFSR and WFDEI is poor as compared to raingauge and observed streamflow might be due to intrusion of error during observed rainfall data assimilation. This indicates the need to modify the rainfall retrieval algorithm for these above-mentioned data due to complex topography and raingauge limitation of the Beas river basin. However after comparing all global reanalysis and meteorological data ERA-Interim is found to give better performance as a meteorological input of the hydrology model. ERA-Interim provides a good match of temperature with observed station data for the whole basin. Moreover, the ERA-Interim temperature has no warmer bias during the simulation period. The 


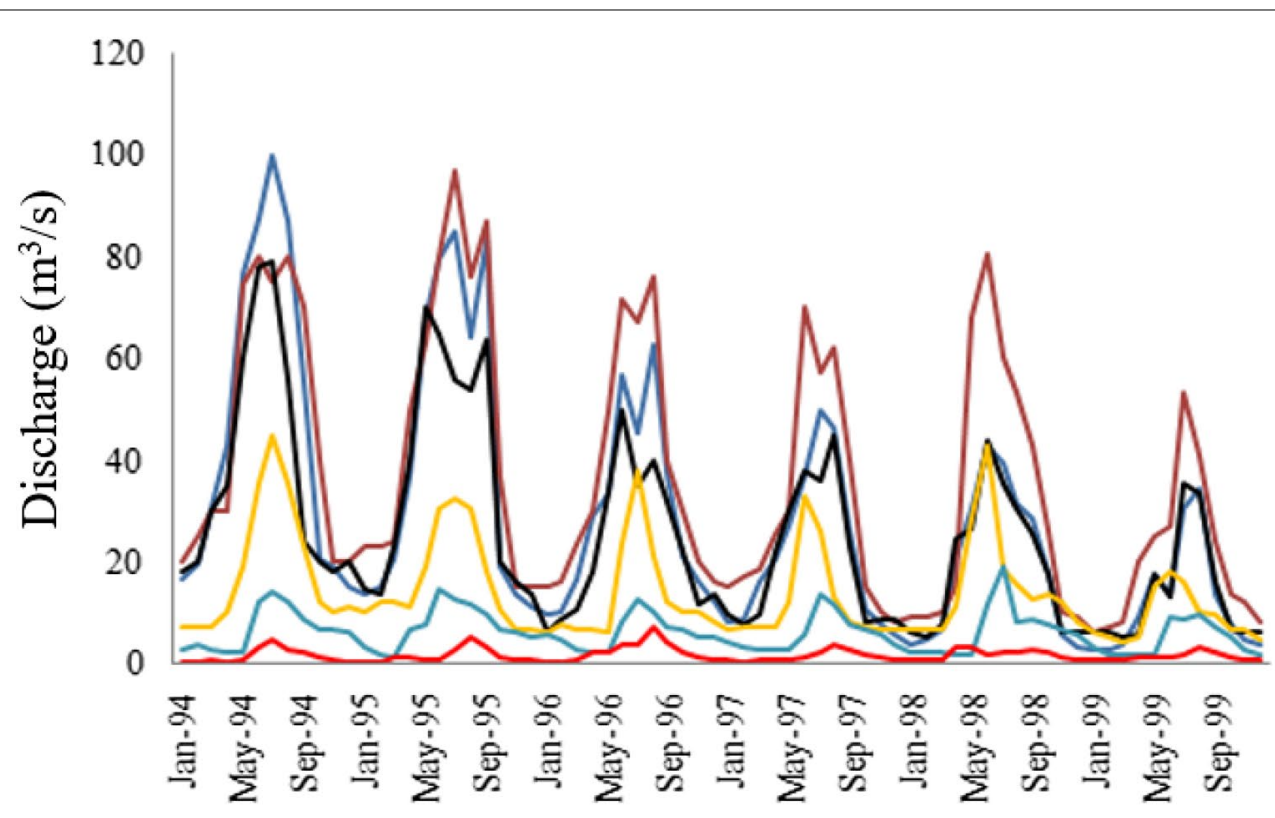

- Observed -MERRA -ERA-INTERIM - JRA-55 - CFSR - WFDEI

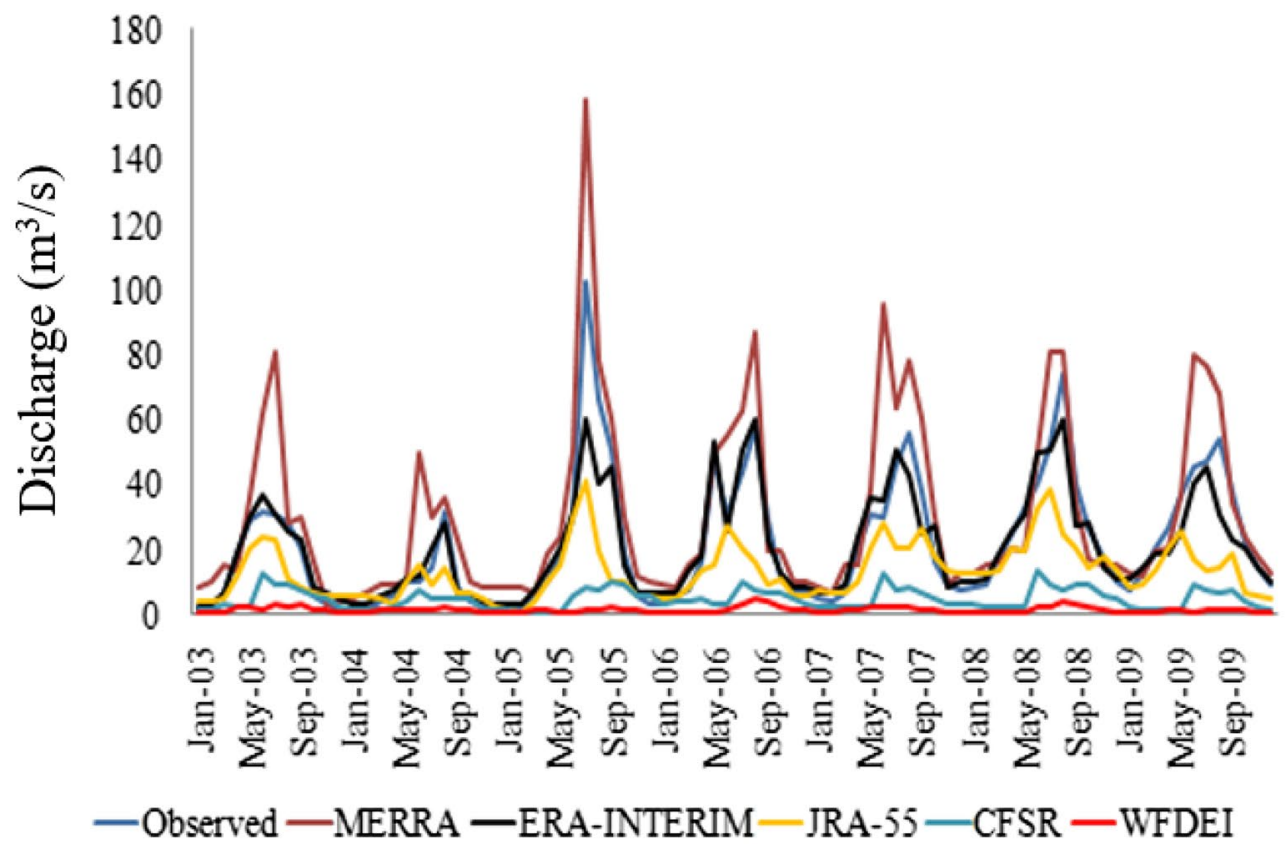

Fig.17 Hydrograph of observed and simulated flow of Manali for calibration period (1994-1999) and validation period (2003-2009)

ERA-Interim rainfall overestimates the observed data seasonally and annually. After the hydrologic simulation, it proves it's potential over observed rainfall data as a good rainfall-runoff input. The reason may be the topographic influence of high altitude Beas is less for
ERA-interim rainfall than other rainfall data. The better performance of ERA-Interim probably due to the assimilation of climate data from observed stations and have the advantage of using a four-dimensional variational analysis model. The reanalysis data is also near 


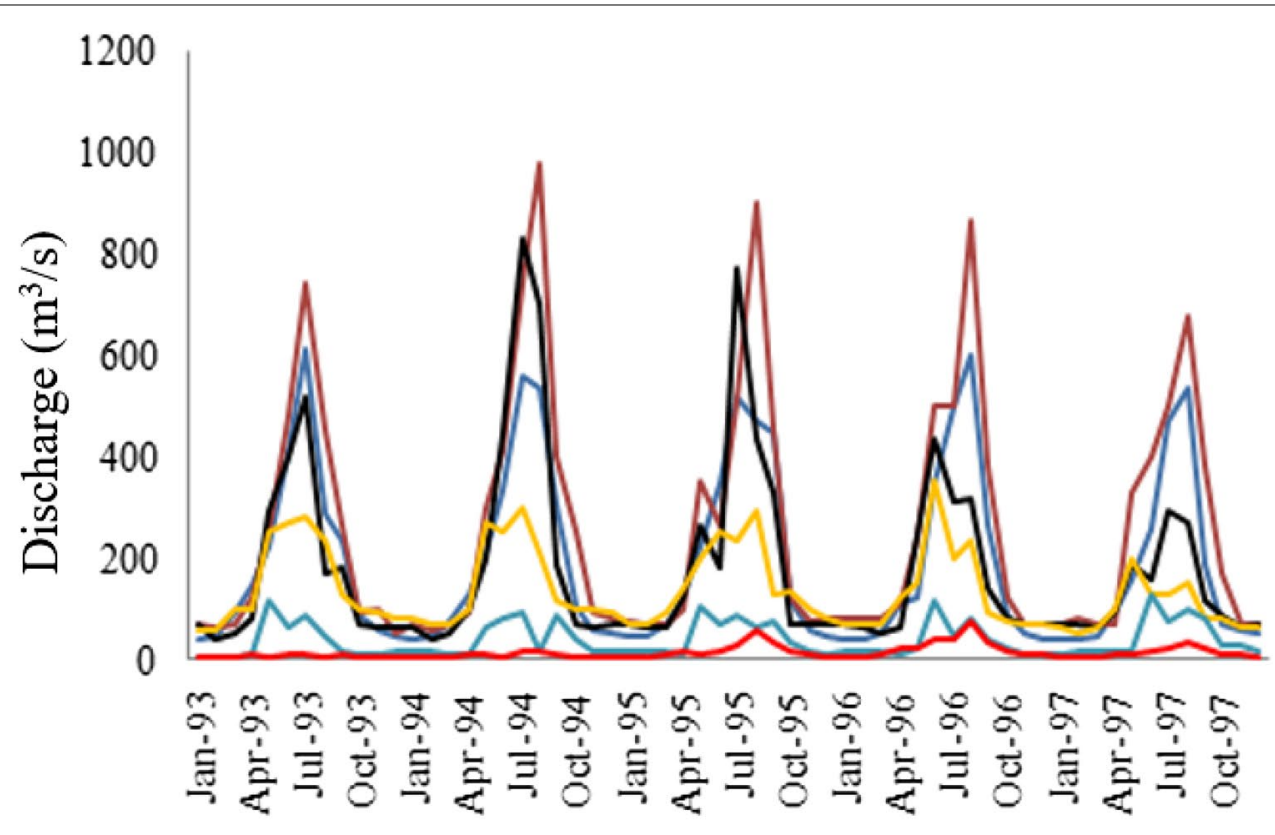

-Observed - MERRA -ERA-INTERIM - JRA-55 - CFSR - WFDEI

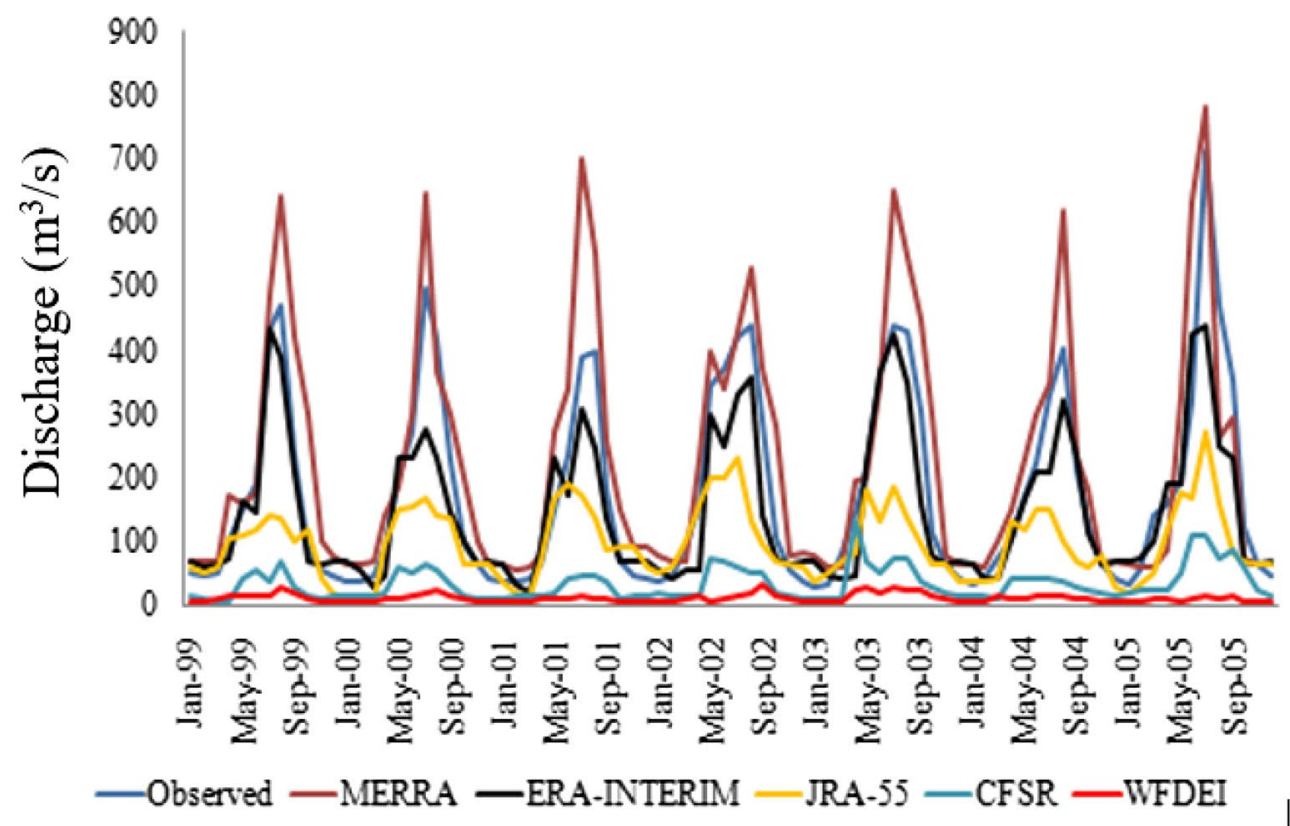

Fig.18 Hydrograph of observed and simulated flow of Thalout for calibration period (1993-1997) and validation period (1999-2005)

real time and daily basis upgraded which is beneficial to proper management of water resources. So high-resolution ERA-Interim reanalysis can be used as a reliable climate data over observations for the data-sparse Beas river basin. The result of the study concludes that the accuracy of rainfall products is responsible for improving hydrology modeling results. This will also help researchers to find out ways of improving the quality of rainfall for hydrology modeling. 


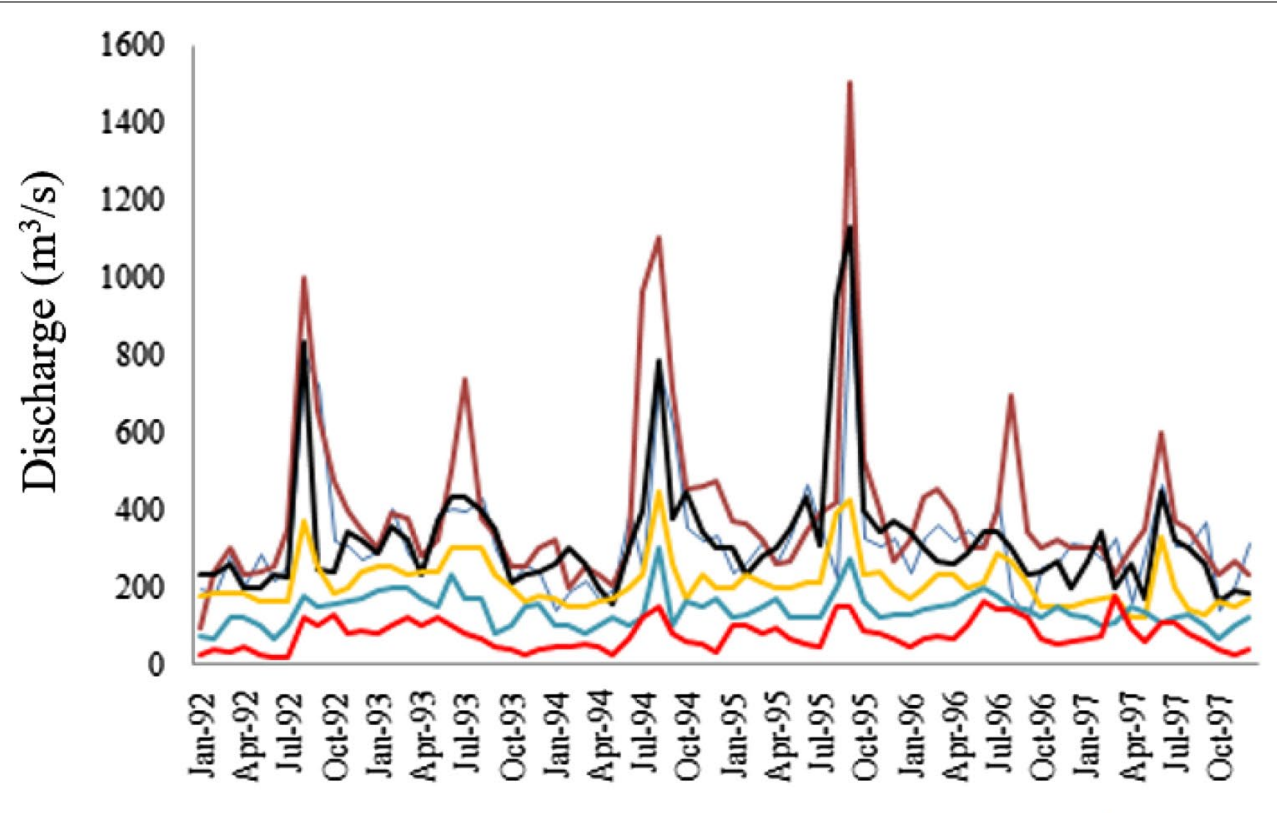

- Observed -MERRA -ERA-INTERIM - JRA-55 — CFSR — WFDEI ।

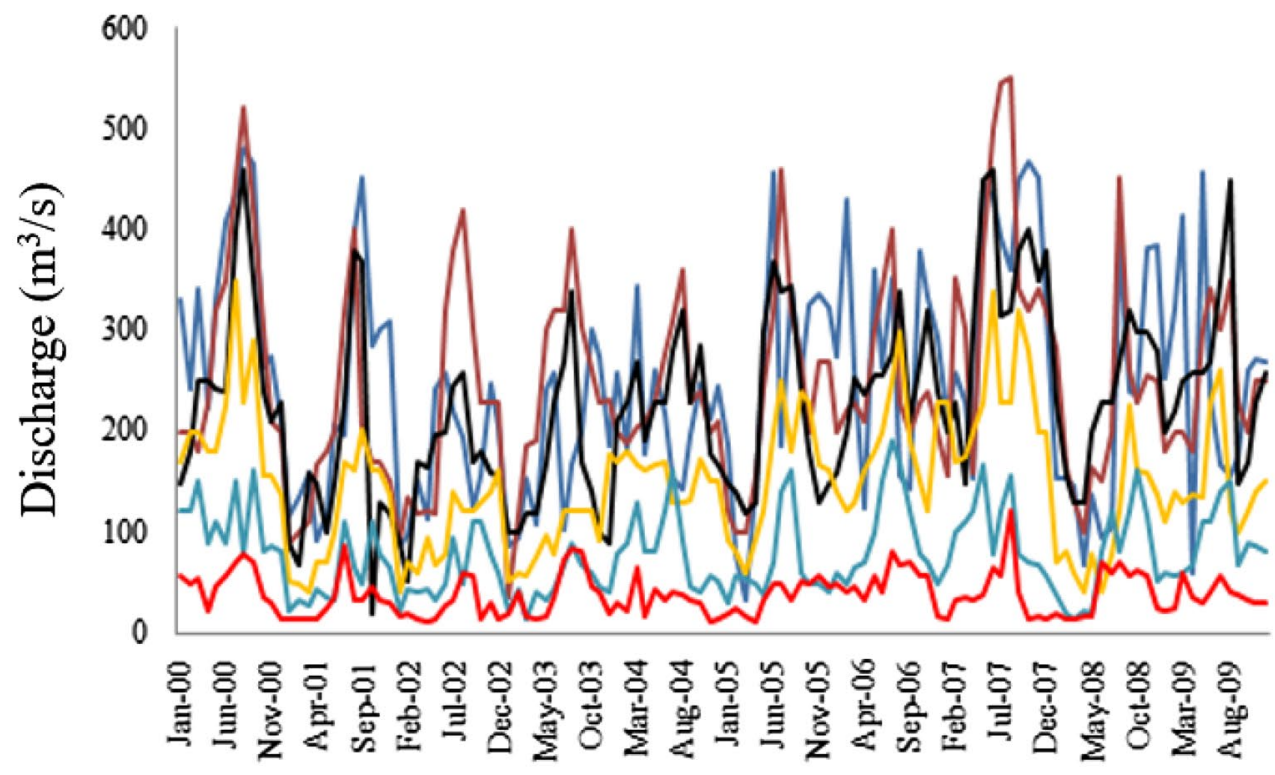

Fig.19 Hydrograph of observed and simulated flow of Pong dam for calibration period (1992-1997) and validation period (2000-2009) 

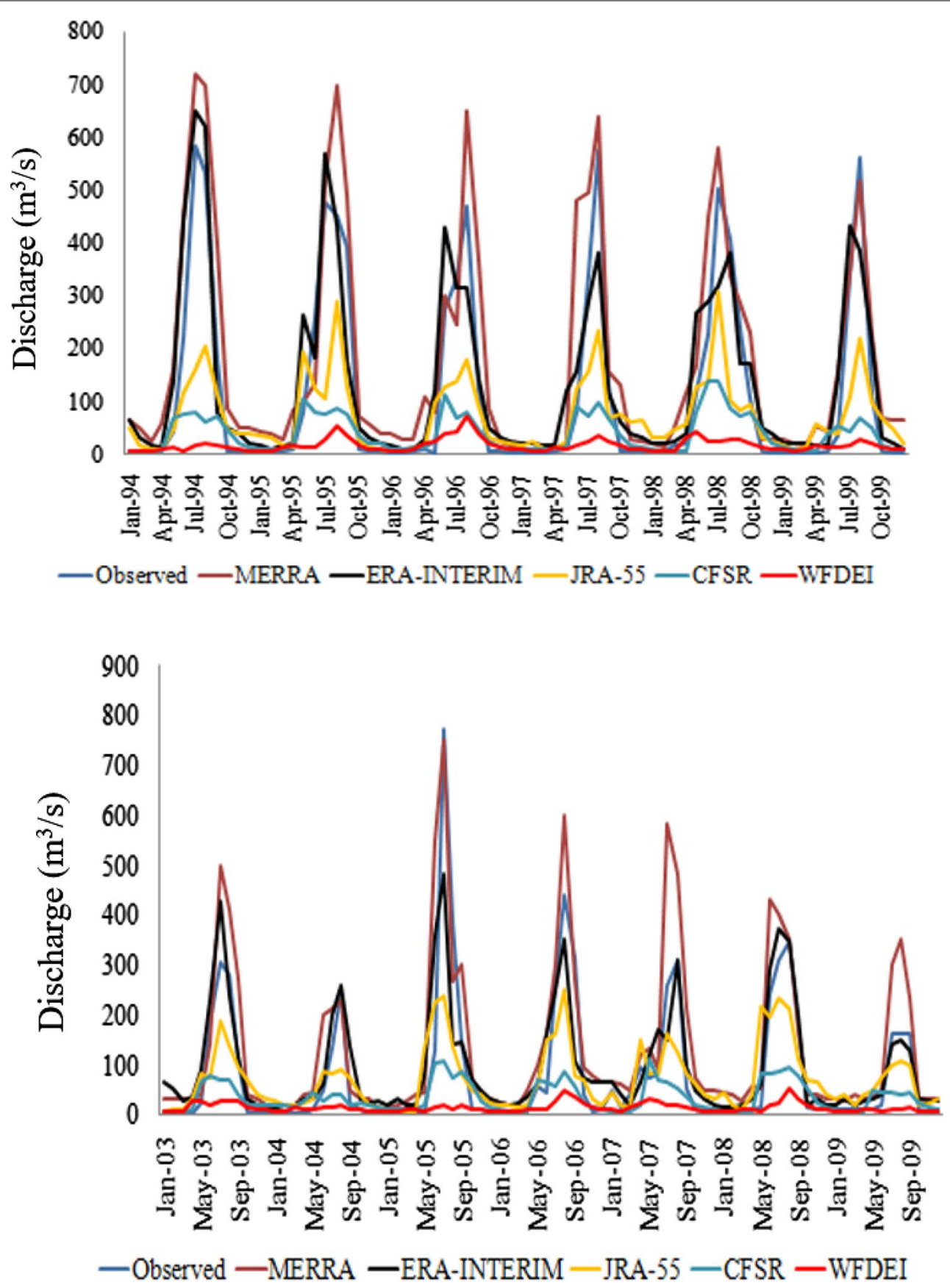

Fig.20 Hydrograph of observed and simulated flow of Pandoh dam for calibration period (1994-1999) and validation period (2003-2009)

\section{Abbreviations}

NCEP: National Centers Of Environmental Prediction; NCAR: National Center For Atmospheric Research; GPCP: Global Precipitation Climatology Project; GPCC: Global Precipitation Climatology Centre; ECMWF: European Center for Medium-Range Weather Forecasts; ERA: Interim-ECMWF reanalysis; CFSR: Climate Forecast System Reanalysis; MERRA: Modern-Era Retrospective Analysis for Research and Applications; WFDEl: Watch forcing data methodology applied to ERA-Interim reanalysis data; VIC: Variable Infiltration Capacity; CRU: Climate Research Unit; GMAO: Global Modeling And Assimilation Office; GEOS:
Goddard Earth Observing System Model; DA: Data Assimilation And Prediction System; 3D-var: Three-dimensional variational approach; 4D-var: Four-dimensional variational approach; NETCDF: Network Common Data Form; Linux: Lovable intellect not using XP; SST: Sea surface temperature; JMA: Japan Meteorological Agency; JRA-55: Japanese 55-year Reanalysis; DEM: Digital Elevation Model; LULC: Land use and land cover; ORNL: Oak Ridge National Laboratory; DAAC: Distributed Active Archive Center; GLDAS: Global Land Data Assimilation System; LAI: Leaf area index; NSE: Nash Sutcliffe Efficiency; $R^{2}$ : Coefficient Of Determination; RMSE: Root Mean Square Error; PBIAS: Percentage Bias. 


\section{Acknowledgements}

We thank anonymous reviewers for technical suggestions on data interpretations.

\section{Author's contributions}

All authors were equally involved in analyzing and editing the paper. All authors read and approved the fnal manuscript.

\section{Funding}

This study was not funded by any grant.

\section{Availability of data and materials}

The data that support the fndings of this study are available from the corresponding author upon request.

\section{Ethics approval and consent to participate}

The authors declare that this manuscript is not published or consider for publication elsewhere.

\section{Consent for publication}

The authors read the manuscript and agree for publication.

\section{Competing interests}

The authors declare that they have no competing interests.

\section{Author details}

${ }^{1}$ Indian Institute of Technology, Roorkee, Uttarakhand, India. ${ }^{2}$ National Institute Of Hydrology, Roorkee, Uttarakahnd, India.

Received: 8 May 2020 Accepted: 15 September 2020

Published online: 26 September 2020

\section{References}

Aggarwal SP, Thakur PK, Garg V, Nikam B, Chouksey A, Dhote P, Bhattacharya T (2016) Water Resources status and availability assessment in current and future climate change scenarios for Beas river basin of NorthWestern Himalaya. Int Arch Photogramm Remote Sens Spatial Inf Sci XLI-B8:1389-1396

Ahluwalia R, Rai SP, Jain SK, Dobhal DP, Kumar A (2015) Estimation of snow/glacier melt contribution in the upper part of the Beas River basin, Himachal Pradesh using conventional and SNOWMOD modeling approach. J Water and Clim Change 6(4):880-890

Arakawa A, Schubert WH (1974) Interaction of a cumulus cloud ensemble with the large-scale environment, Part I. J Atmos Sci 31:674-701

Ashouri H, Hsu KL, Sorooshian S, Braithwaite DK, Knapp KR, Cecil LD, Nelson BR, Prat OP (2015) PERSIANN-CDR: Daily precipitation climate data record from multisatellite observations for hydrological and climate studies. Bull Am Meteorol Soc 96:69-83

Bai P, Liu X (2018) Evaluation of five satellite-based precipitation products in two gauge-scarce basins on the Tibetan Plateau. Remote Sens 10(8):1-22

Bao X, Zhang F (2013) Evaluation of NCEP-CFSR, NCEP-NCAR, ERA-Interim, and ERA-40 Reanalysis Datasets against Independent Sounding Observations over the Tibetan Plateau. J Clim 26:206-214

Barros AP, Kim G, Williams E, Nesbitt SW (2004) Probing orographic controls in the Himalaya during the Monsoon using satellite imagery. Nat Hazards Earth Syst Sci 4:29-51

Beck HE, Vergopolan N, Pan M, Levizzani V, Dijk AIJMV, Weedon GP, Brocca L, Pappenberger F, Huffman GJ, Wood EF (2017a) Global-scale evaluation of 22 precipitation datasets using gauge observations and hydrological modeling. Hydrol Earth Syst Sci 21:6201-6217

Beck HE, Van Dijk AIJM, Levizzani V, Schellekens J, Miralles DG, Martens B, De Roo A (2017b) MSWEP: 3-hourly 0.25 global gridded precipitation (1979-2015) by merging gauge, satellite and reanalysis data. Hydrol Earth syst sci 21(1):589-615

Beck HE, Wood EF, Pan M, Fisher CK, Miralles DG, Van Dijk AIJM, Mcvicar TR, Adler RF (2018) MSWEP V2 global 3-hourly 0.1 precipitation: Methodology and quantitative assessment. Bull Am Meteorol Soc. https://doi. org/10.1175/BAMS-D-17-0138.1

Beven K (2006) A manifesto for the equifinality thesis. J Hydrol 320:18-36
Bhattacharya T, Khare D, Arora M (2019) A case study for the assessment of the suitability of gridded reanalysis weather data for hydrological simulation in Beas river basin of North-Western Himalaya. Appl Water Sci 9(110):1-15

Blacutt LA, Herdies DL, Goncalves L, Villa DA, Andrade M (2015) Precipitation comparison for the CFSR, MERRA, TRMM 3B42 and combined scheme datasets in Bolivia. Atm Res 163:117-131

Bosilovich MG, Chen J, Robertson FR, Adler RF (2008) Evaluation of global precipitation in reanalysis. J appl Meteor climatol 47:2279-2299

Bosilovich MG, Robertson FR, Chen J (2011) Global energy and water budgets in MERRA. J Clim 24:5721-5739

Buytaert W, Friesen J, Liebe J, Ludwig R (2012) Assessment and management of water resources in developing, semi arid and arid regions. Water Resour Manag 26:841-844

Caroletti GN, Coscarelli R, Caloiero T (2019) Validation of satellite, reanalysis and RCM data of monthly rainfall in Calabria (Southern Italy). Remote Sens $11: 1625$

Chen B, Liu Z (2016) Global water vapour variability and trend from the latest 36 year (1979-2014) data of ECMWF and NCEP reanalyses, radiosonde, GPS, and microwave satellite. J Geophys Res Atmos 121:11-442

Cherkauer KA, Lettenmaier DP (1999) Hydrologic effects of frozen soils in the Upper Mississippi river basin. J Geophys Res 104:19599-19610

Clark MP, Kavetski D, Fenicia F (2011) Pursuing the method of multiple working hypotheses for hydrological modeling. Water Resor Res 47(9):1-16

Dee DP et al (2011) The ERA-Interim reanalysis: configuration and performance of the data assimilation system. Q J R Meteorol Soc 137:553-597

Derin Y, Yilmaz KK (2014) Evaluation of multiple satellite-based precipitation products over complex topography. J Hydrometeorol 15(4):1498-1516

Duethmann D, Zimmer J, Gafurov A, Gunter A, Kriegel D, Merz B, Vorogushyn $S$ (2013) Evaluation of areal precipitation estimates based on downscaled reanalysis and station data by hydrological modeling. Hydrol Earth Syst Sci 17:2415-2434

Essou GRC, Sabarly F, Lucas-Picher P, Brissette F, Poulin A (2016a) Can precipitation and temperature from meteorological reanalyses be used for hydrological modeling? J Hydrometeorol 17:1929-1950

Essou GR, Arsenault R, Brissette FP (2016b) Comparison of climate datasets for lumped hydrological modeling over the continental United States. J Hydrol 537:334-345

Essou GRC, Brissette F, Picher PL (2017) The use of reanalyses and gridded observations as weather input data for a hydrological model: comparison of performances of simulated river flows based on the density of weather stations. J Hydrometeorol 18:497-513

Fu S, Sonnenborg TO, Jesen KH, He X (2011) Impact of precipitation spatial resolution on the hydrological response of an integrated distributed water resources model. Vadose Zone J 10:25-36

Fujiwara M et al (2017) Introduction to the SPARC reanalysis intercomparison project(S-RIP) and overview of the reanalysis systems. Atmos Chem Phys 17:1417-1452

Fuka DR, Walter MT, MacAlister C, Degaetano AT, Steenhuis TS, Easton ZM (2014) Using the climate forecast system reanalysis as weather input data for watershed models. Hydrol Processes 28:5613-5623

Ghodichore N, Vinnarasi R, Dhanya CT, Roy SB (2018) Reliability of reanalyses products in simulating precipitation and temperature characteristics over India. J Earth Sys Sci 127:115

Goodison BE, Louie PYT, Yang D (1998) WMO Solid Precipitation Measurement Intercomparison; Final Report, WMO instruments and observing methods report no. 67, WMO/TD-No. 872, Geneva, Switzerland: World Meteorol Organisation.

Gupta HV, Sorooshian S, Yapo PO (1999) Status of automatic calibration for hydrologic models:comparison with multilevel expert calibration. J Hydrol Eng 4(2):135-143

Haddeland I, Matheussen BV, Lettenmaier DP (2002) Influence of spatial resolution on simulated streamflow in a macroscale hydrologic model. Water Resour Res 38:291-2910

Harris I, Jones PD, Osborn TJ, Lister DH (2014) Updated high-resolution grids of monthly climatic observations-the CRU TS 3.10. Int J Climatol 34:623-642

Haylock MR, Hofstra N, Klein Tank AMG, Klok EJ, Jones PD, New M (2008) A European daily high-resolution gridded dataset of surface temperature and precipitation of 1950-2006. J Geophys Res 113(D20):12

Henn B, Clark MP, Kavetski D, Lundquist JD (2015) Estimating mountain basinmean precipitation from streamflow using Bayesian inference. Water Resour Res 51:8012-8033 
Hodges KI, Lee RW, Bengtsson L (2011) A comparison of extratropical cyclones in recent reanalysis ERA-Interim, NASA MERRA, NCEP CFSR and JRA-25. J Clim 24:4888-4906

Hong Y, Hsu KL, Moradkhani H, Sorooshian S (2006) Uncertainty quantification of satellite precipitation estimation and Monter Carlo assessment of the error propagation into hydrologic response. Water Resour Res 42(8):15

Islam SU, Dery SJ (2017) Evaluating uncertainties in modeling the snow hydrology of the Fraser river basin, British Columbia, Canada. Hydrol Earth Syst Sci 21:1827-1847

Janjic T, Bormann N, Bocquet M, Carton JA, Cohn SE, Dance SL, Losa SN, Nichols NK, Potthast R, Waller JA, Weston P (2017) On the representation error in data assimilation. Q J R Meteorol Soc 144(713):1257-1278

Janowiak JE et al (1998) A comparison of the NCEP-NCAR reanalysis precipitation and the GPCP raingauge-satellite combined dataset with observational error considerations. J Clim 11(11):2960-2979

Kobayashi S, National center for Atmospheric research staff (eds) (2020) The climate data guide- JRA-55. https://climatedataguide.ucar.edu/clima te-data/jra-55. Accessed 4 Sep 2020

Kobayashi S et al (2015) The JRA-55 reanalysis: general specifications and basic characteristics. J Met Soc Jap 93(1):5-48

Krause P, Boyle DP, Base F (2005) Comparison of different efficiency criteria for hydrological model assessment. Adv Geosci 5:89-97

Kumar V, Singh P, Singh V (2007) Snow and glaciermelt contribution in the Beas river at Pandoh dam, Himachal Pradesh. India Hydrol Sci J 52(2):376-388

Ledesma JL, Futter MN (2017) Gridded climate data products are an alternative to instrumental measurements as inputs to rainfall-runoff models. Hydrol Processes 31(18):3283-3293

Li P (1995) Distribution of snow cover over the High Asia. J Glaciol Geocryol 17:291-298

Li Lu, Engelhardt M, Xu CY, Jain SK, Singh VP (2013) Comparison of satellitebased and reanalysed precipitation as input to glaciohydrologicalmodeling for Beas river basin, Northern India. Cold and Mountain Region Hydrological Systems Under ClimateChange: Towards Improved Projections: Proceedings of H02, IAHS-IAPSO-IASPEI Assembly, Gothenburg, Sweden, 22-26 July2013 IAHS Publ, 360, pp 45-52

$\mathrm{Li} \mathrm{H}$ et al (2015) Integrating a glacier retreat model into a hydrological model-Case studies of three glacierised catchments in Norway and Himalayan region. J Hydrol 527:656-667

Li Lu, Gochis DJ, Sobolowski S, Mesquita MDS (2017) Evaluating the present annual water budget of a Himalayan headwater river basin using a high-resolution atmosphere-hydrology model. J Geophys Res 122(9):4786-4807

Liang X, Lettenmaier DP, Wood EF, Burges SJ (1994) A simple hydrologically based model of land surface water and energy fluxes for general circulation models. J Geophys Res 99(D7):14415-14428

Lin R, Zhou T, Qian Y (2014) Evaluation of global Monsoon precipitation changes based on five reanalysis datasets. J Clim 27:1271-1289

Liu C, Zipser EJ (2014) Differences between the surface precipitation estimaes from the TRMM precipitation radar and passive microwave radiometer version 7 products. J Hydrometeorol 15:2157-2175

Lobligeois F, Andreassian V, Perrin C, Tabary P, Loumagne C (2014) When does higher spatial resolution rainfall information improve streamflow simulation? An evaluation using 3620 flood events. Hydrol Earth Syst Sci 18:575-594

Maraun D (2013) Bias-correction, quantile mapping, and downscaling: revisiting the inflation issue. J Clim 26:2137-2143

Maurer EP et al (2002) A long-term hydrologically based dataset of land surface fluxes and states for the conterminous United States. I Clim 15(22):3237-3251

Mei Y, Nikolopoulos El, Anagnostou EN, Borga M (2016) Evaluating satellite precipitation error propagation in runoff simulations of Mountainous basins. J Hydrometeorol 17:1407-1423

Moriasi D, Arnold J, Liew V, Bingner R, Harmel R, Veith T (2007) Model evaluation guidelines for systematic quantification of accuracy in watershed simulations. Trans ASABE 50(3):885-900

Moulin L, Gaume E, Obled C (2009) Uncertainties on mean areal precipitation: Assessment and impact on streamflow simulations. Hydrol Earth Syst Sci 13:99-114
Nesbitt SW, Anders AM (2009) Very high reolution precipitation climatologies from the Tropical Rainfall Measuring Misiion precipitation radar. Geophys Res Lett 36(15):1-5

Nijssen B, Lettenmaier DP, Liang X, Wetzel SW, Wood EF (1997) Streamflow simulation for continental-scale river basins. Water Resour Res 33(4):711-724

Nkiaka E, Nawaz NR, Lovett JC (2017) Evaluating global reanalysis datasets as input for hydrological modeling in the Sudano-Sahel region. Hydrology $4(1): 1-19$

Olauson J (2018) ERA5: the new champion of wind power modeling? Renew Energy 126:322-331

Oudin L, Perrin C, Mathevet T, Andréassian V, Michel C (2006) Impact of biased and randomly corrupted inputs on the efficiency and the parameters of watershed models. J Hydrol 320:62-83

Palazzi E, von Hardenberg J, Provenzale A (2013) Precipitation in the HinduKush Karakoram Himalaya: observations and future scenarios. J Geophys Res 118:85-100

Parker WS (2016) Reanalyses and observations:what's the differen? Bull Amer Meteor Soc 97:1565-1572

Rabier F, Thépaut JN, Courtier P (1998) Extended assimilation and forecast experiments with a four-dimensional variational assimilation system. Q J R Meteorol Soc 124:1861-1887

Rabier F, Jarvinen H., Klinker E, Mahfouf JF, Simmons A (2000) The ECMWF operational implementation of four dimensional variational assimilation. Part I: Experimental results with 15 simplified physics. Q J R Meteor Soc 126:1143-1170

Rasmussen R et al (2012) How well are we measuring snow: The NOAA/FAA/ NCAR Winter precipitation test bed. Bull Amer Meteor Soc 93:811-829

Rienecker MM et al (2011) MERRA—NASA's modern-era retrospective analysis for research and applications. J Clim 24:3624-3648

Rolland C (2003) Spatial and seasonal variations of air temperature lapse rates in Alpine regions. J Clim 16:1032-1046

Roy PS et al (2015) Development of decadal (1985-1995-2005) land use and land cover database for India. Remote Sens 7:2401-2430

Saha $S$ et al (2010) The NCEP climate forecast system reanalysis. Bull Amer Meteor Soc 91:1015-1057

Saha $S$ et al (2014) The NCEP climate forecast system version 2. J Clim 27:2185-2208

Sevruk B, Mieglitz K (2002) The effect of topography, season and weather simulation on daily precipitation gradients in 60 swiss valleys. Water Sci Technol 45:41-48

Shah R, Mishra V (2014) Evaluation of the reanalysis products for the Monsoon seasons droughts in India. J Hydrometeor 15:1575-1591

Shea DJ, Worley SJ, Stern IR, Hoar TJ (1994) An introduction to atmospheric and oceanographic data. Natl Cent Atmos Res Boulder Colo Tech 404:138

Shen Y, Xiong A, Wang Y, Xie P (2010) Performance of high-resolution satellite precipitation products over China. J Geophys Res 115(D2):1-17

Shrestha M, Koike T, Hirabayashi Y, Xue Y, Wang L, Ghulam R, Ahmad B (2015) Integrated simulation of snow and glacier melt in water and energy balance based, distributed hydrological modeling framework at Hunza river basin of Pakistan Karakoram region. J Geophys Res Atmos 120(10):4889-4919

Simmons AJ, Willett KM, Jones PD, Thorne PW, Dee DP (2010) Low-frequency variations in surface atmospheric humidity, temperature and precipitation: Inferences from reanalyses and monthly gridded observational datasets. J Geophys Res 115:1-21

Singh P, Jain SK (2002) Snow and glaciermelt in the satluj river at Bhakra dam in the Western Himalayan region. Hydrol Sci 47(1):93-106

Sun Q, Miao C, Duan Q, Ashouri H, Sorooshian S, Hsu KL (2018) A review of global precipitation datasets: data sources, estimation, and intercomparisons. Rev Geophys 56:79-107

Thiemig V, Rojas R, Zambrano-Bigiarini M, De Roo A (2013) Hydrological evaluation of satellite-based rainfall estimates over the Volta and Baro-Akobo Basin. J Hydrol 499:324-338

Tiwari S, Kar SC, Bhatla R, Bansal R (2018) Temperature index based snowmelt runoff modeling for the Satluj Riverbasin in the Western Himalayas. Meteorol Appl 25:302-313

Tong K, Su F, Yang D, Hao Z (2014a) Evaluation of satellite precipitation retrievals and their potential utilities in hydrologic modeling over the Tibetan Plateau. J hydrol 519:423-437 
Tong K, Su F, Yang D, Zhang L, Hao Z (2014b) Tibetan Plateau precipitation as depicted by gauge observations, reanalyses and satellite retrievals. Int J Climatol 34(2):265-285

Trenberth KE, Fasullo JT, Mackaro J (2011) Atmospheric moisture transports from ocean to land and global energy flows in reanalyses. J Clim 24:4907-4924

Walter MT, Brooks ES, McCool LG, King MM, Boll J (2005) Process-based snowmelt modeling:does it require more input data than temperature-index modeling? J Hydrol 300:65-75

Wang W, Xie P, Yoo SH, Xue Y, Kumar WuX (2011) An assessment of the surface climate in the NCEP Climate Forecast System Reanalysis. Clim Dyn 37:1601-1620

Ward E et al (2011) Evaluation of precipitation products over complex mountainuous terrain: A water resources perspective. Adv Water Res 34(10):1222-1231

Weedon GP, Balsamo G, Bellouin N, Gomes S, Best MJ, Viterbo P (2014) The WFDEI meteorological forcing data set: WATCH forcing data methodology applied to ERA-Interim reanalysis data. Water Resour Res 50:7505-7514
Xie P, Chen M, Yatagai A, Hayasaka T, Fukushima Y, Yang S (2007) A gaugebased analysis of daily precipitation over East Asia. J Hydrometeor 8:607-626

Yanto LB, Rajagopalan B (2017) Development of a gridded meteorological dataset over Java island, Indonesia 1985-2014. Sci Data 4:1-10

Zhao TB et al (2010) Global atmosphere reanalysis datasets: current status and recent advances. Adv Earth Sci 25(3):242-254

Zhao F, Zhang L, Chiew FHS, Vaze J, Cheng L (2013) The effect of spatial rainfall variability on water balance modeling for South-Eastern Australian catchments. J Hydrol 493:16-29

Zoppou C (2000) Review of urban storm water models. Environ Model Softw $16: 195-231$

\section{Publisher's Note}

Springer Nature remains neutral with regard to jurisdictional claims in published maps and institutional affiliations.

\section{Submit your manuscript to a SpringerOpen ${ }^{\circ}$ journal and benefit from:}

- Convenient online submission

- Rigorous peer review

- Open access: articles freely available online

- High visibility within the field

- Retaining the copyright to your article

Submit your next manuscript at springeropen.com 